Cover. Big Lost River, looking upstream (north) toward the Lost River Range, south-central Idaho. Photograph by Lauren M. Zinsser, U.S. Geological Survey, during the October 16, 2019, measurement event near the Moore Diversion. 


\section{Surface-Water and Groundwater Interactions in the Big Lost River, South-Central Idaho}

By Taylor J. Dudunake and Lauren M. Zinsser

Chapter B of

Characterization of Water Resources in the Big Lost River Basin, South-Central Idaho

Edited by Lauren M. Zinsser

Prepared in cooperation with the Idaho Department of Water Resources

Scientific Investigations Report 2021-5078-B 


\section{U.S. Geological Survey, Reston, Virginia: 2021}

For more information on the USGS - the Federal source for science about the Earth, its natural and living resources, natural hazards, and the environment—visit https://www.usgs.gov or call 1-888-ASK-USGS.

For an overview of USGS information products, including maps, imagery, and publications, visit https://store.usgs.gov/.

Any use of trade, firm, or product names is for descriptive purposes only and does not imply endorsement by the U.S. Government.

Although this information product, for the most part, is in the public domain, it also may contain copyrighted materials as noted in the text. Permission to reproduce copyrighted items must be secured from the copyright owner.

Suggested citation:

Dudunake, T.J., and Zinsser, L.M., 2021, Surface-water and groundwater interactions in the Big Lost River, south-central Idaho, chap. B of Zinsser, L.M., ed., Characterization of water resources in the Big Lost River Basin, south-central Idaho: U.S. Geological Survey Scientific Investigations Report 2021-5078-B, 33 p., https://doi.org/ 10.3133/sir20215078B.

ISSN 2328-0328 (online) 


\section{Preface}

This is the second of three reports in a multichapter volume characterizing water resources in the Big Lost River Basin. These reports document the findings of a hydrogeologic investigation of the Big Lost River Basin that was jointly conducted by the U.S. Geological Survey, Idaho Department of Water Resources, and the Idaho Geological Survey from 2018 through 2021. Chapter A (Zinsser, 2021) describes the hydrogeologic framework of the Big Lost River Basin. It includes a conceptual definition of the hydrogeologic units, a three-dimensional hydrogeologicframework model, and a description of groundwater occurrence and movement. Chapter B (this report) describes streamflow gains from and losses to groundwater in the Big Lost River between Mackay Reservoir and south of Arco, Idaho. Streamflow gains and losses were estimated from a series of four surface-water measurement events during pre- and post-irrigation season conditions from 2019 to 2021. Chapter C (Clark, 2022) describes groundwater budgets for the Big Lost River Basin from 2000 to 2019. The groundwater budgets provide annual estimates for aquifer inflows and outflows. Collectively, these reports present a characterization of water resources in the Big Lost River Basin that will help address current challenges in water-resource management. 


\section{Acknowledgments}

The authors thank the Idaho Department of Water Resources (IDWR) and U.S. Geological Survey (USGS) staff who supported the data collection effort, including Ethan Giesler, David Hoekema, Dennis Owsley, and Amy Steimke (IDWR) and Jay Bateman, John Carricaburu, Joshua Donnelly, Jeremy Green, Darrin Miller, Ryan Moore, John Spruell, Brad Vande Kamp, and Jacob Williams (USGS). The dedication and support from these individuals were essential in providing dependable data for this study. Special thanks also to Lucas Yocke, watermaster of the Big Lost River Irrigation District (BLRID), for insightful knowledge and stable water release conditions that aided data collection and interpretation. This study would not have been possible without property access from multiple landowners in the valley. 


\section{Contents}

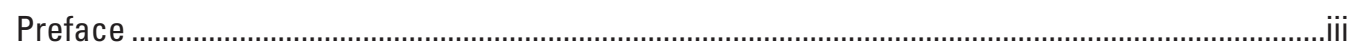

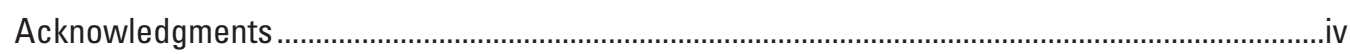

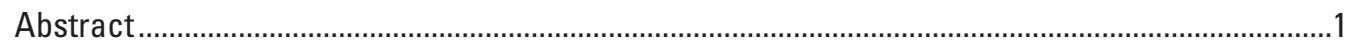

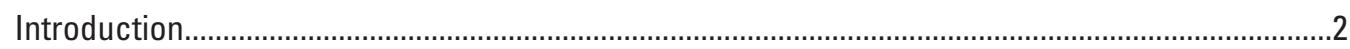

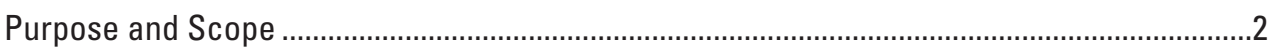

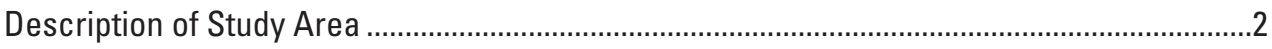

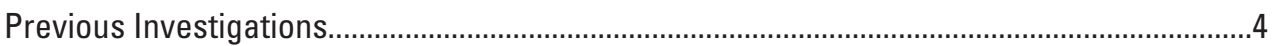

Methods

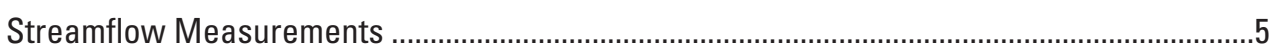

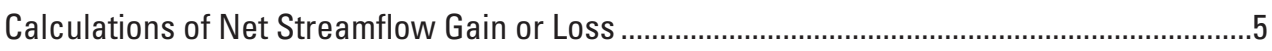

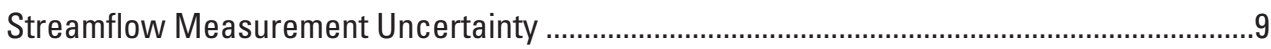

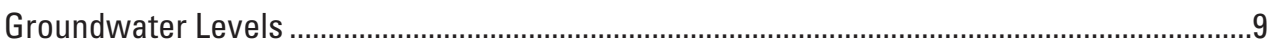

Results for Streamflow Gains and Losses ..........................................................................11

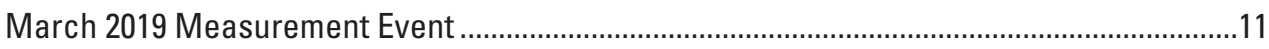

October 2019 Measurement Event.......................................................................................11

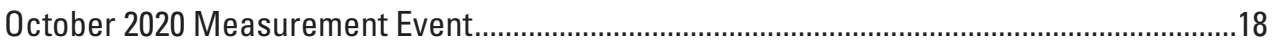

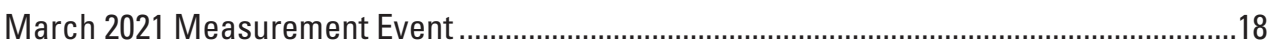

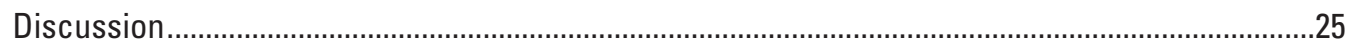

Summary

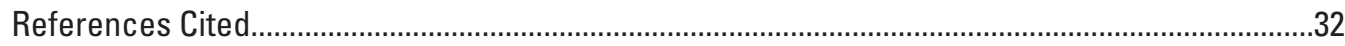

\section{Figures}

1. Maps showing streamflow measurement sites, communities, and other features in the Big Lost River Basin, south-central Idaho ..................................................3

2. Map showing gaining and losing reaches and subreaches on the Big Lost River, south-central Idaho, March 2019

3. Map showing gaining and losing reaches and subreaches on the Big Lost River, south-central Idaho, October 2019

4. Map showing gaining and losing reaches and subreaches on the Big Lost River, south-central Idaho, October 2020

5. Map showing gaining and losing reaches and subreaches on the Big Lost River, south-central Idaho, March 2021

6. Graphs showing comparison of measured streamflow gain and loss with measurement uncertainty in each subreach, Big Lost River Valley, south-central Idaho.

7. Graphs showing snow water equivalent on May 1, 2017-21, compared to median for Snow Telemetry (SNOTEL) sites, for water years 2017-21; total annual precipitation for water years 2017-20; and surface-water supply index for water years 2017-21, in the Big Lost River Basin, south-central Idaho.

8. Hydrographs showing groundwater potentiometric surface altitudes in shallow wells at well cluster sites and Big Lost River streamflow at select streamgages in the Big Lost River Valley, south-central Idaho, 2019-21

9. Map showing groundwater potentiometric surface altitudes in Big Lost River Valley, south-central Idaho, March 2019 and March 2021

10. Map showing groundwater potentiometric surface altitudes in Big Lost River Valley, south-central Idaho, October 2019 and October 2020 


\section{Tables}

1. Streamflow measurement sites and measurement conditions, Big Lost River Valley, south-central Idaho, March and October 2019, October 2020, and March 2021

2. Groundwater-level monitoring wells and potentiometric surface altitudes during surface-water measurement events, Big Lost River Basin, south-central Idaho.

3. Summary of streamflow, associated estimates of uncertainty, and streamflow gains and losses on measured reaches and subreaches in the Big Lost River Valley, south-central Idaho, March 27-28, 2019.

4. Summary of streamflow, associated estimates of uncertainty, and streamflow gains and losses on measured reaches and subreaches in the Big Lost River Valley, south-central Idaho, October 16-17, 2019

5. Summary of streamflow, associated estimates of uncertainty, and streamflow gains and losses on measured reaches and subreaches in the Big Lost River Valley, south-central Idaho, October 6-7, 2020

6. Summary of streamflow, associated estimates of uncertainty, and streamflow gains and losses on measured reaches and subreaches in the Big Lost River Valley, south-central Idaho, March 30, 2021

\section{Conversion Factors}

U.S. customary units to International System of Units

\begin{tabular}{lll}
\hline \multicolumn{1}{c}{ Multiply } & \multicolumn{1}{c}{ By } & \multicolumn{1}{c}{ To obtain } \\
\hline foot $(\mathrm{ft})$ & \multicolumn{1}{c}{ Length } & meter $(\mathrm{m})$ \\
mile $(\mathrm{mi})$ & 0.3048 & kilometer $(\mathrm{km})$ \\
\hline \multicolumn{3}{c}{ Area } \\
\hline square mile $\left(\mathrm{mi}^{2}\right)$ & 1.609 & square kilometer $\left(\mathrm{km}^{2}\right)$ \\
\hline \multicolumn{2}{c}{ Flow rate } & \\
\hline cubic foot per second $\left(\mathrm{ft}^{3} / \mathrm{s}\right)$ & 2.590 & cubic meter per second $\left(\mathrm{m}^{3} / \mathrm{s}\right)$ \\
\hline
\end{tabular}

\section{Datums}

Vertical coordinate information, where known, is referenced to the North American Vertical Datum of 1988 (NAVD 88).

Horizontal coordinate information is referenced to the North American Datum of 1983 (NAD 83).

Altitude, as used in this report, refers to distance above the vertical datum (where known). 


\section{Abbreviations}

ADCP acoustic Doppler current profiler

ADV acoustic Doppler velocimeter

BLRID Big Lost River Irrigation District

BLRV Big Lost River Valley

IDWR Idaho Department of Water Resources

USGS U.S. Geological Survey 



\title{
Surface-Water and Groundwater Interactions in the Big Lost River, South-Central Idaho
}

\author{
By Taylor J. Dudunake and Lauren M. Zinsser
}

\section{Abstract}

The Big Lost River of south-central Idaho interacts with the underlying aquifer by gaining and losing streamflow throughout various areas in the Big Lost River Valley. Surfacewater and groundwater resources are used throughout the valley to sustain domestic, agricultural, and livestock needs. The U.S. Geological Survey, in cooperation with the Idaho Department of Water Resources, evaluated streamflow gains and losses by differential streamgaging in the lower Big Lost River, Idaho, during four measurement events: March 27-28, 2019; October 16-17, 2019; October 6-7, 2020; and March 30, 2021. This report presents and analyzes streamflow measurement and uncertainty data from each measurement event to describe surface-water/groundwater interactions. Results from this investigation will improve the understanding of water resources in the Big Lost River Valley and assist in water-management decision-making. This report is the second chapter of a multi-chapter volume that characterizes water resources in the Big Lost River Basin.

During the four measurement events, 100 streamflow measurements were made at 46 unique sites on the Big Lost River, James Creek, and diversions or tributaries between Mackay Reservoir near Mackay and Arco, Idaho. In the upper reach of the Big Lost River, located between Mackay Reservoir and Leslie, overall net streamflow gains, losses, and measurement uncertainty were small (about 10 cubic feet per second $\left[\mathrm{ft}^{3} / \mathrm{s}\right]$ ) in the first three events, with a net loss of $23.0 \pm 5.80 \mathrm{ft}^{3} / \mathrm{s}$ in the March 2021 event. The middle reach, stretching from Leslie to the Moore Diversion and encompassing the Darlington Sinks, had consistent overall losses, ranging from $7.36 \pm 9.91 \mathrm{ft}^{3} / \mathrm{s}$ in October 2019 to $85.3 \pm 14.6 \mathrm{ft}^{3} / \mathrm{s}$ in October 2020. The lower reach, from the Moore Diversion to downstream from Arco, only had substantial streamflow during the 2019 events but had overall net losses during each event $\left(39.9 \pm 1.88 \mathrm{ft}^{3} / \mathrm{s}\right.$ in March 2019 and $50.8 \pm 9.01 \mathrm{ft}^{3} / \mathrm{s}$ in October 2019).
Aquifer lithology and dimensions affected spatial patterns of streamflow gains and losses between the upper, middle, and lower reaches; changes in water supply, groundwater levels, and surface-water management affected seasonal differences within reaches. The 2019 measurement events were preceded by three winters with high or close-to-median snowpack and abundant or close-to-normal surface-water supply, whereas the 2020 and 2021 events were preceded by one and two winters, respectively, with low snowpack and below-normal surface-water supply. In the upper reach of the Big Lost River, streamflow losses and gains were greater during the wetter 2019 events and lesser during the drier 2020 and 2021 events. The middle reach includes the largest losses from the Big Lost River to groundwater; these losses occurred in the Darlington Sinks downstream from Leslie where 42 percent or more of streamflow was lost as the aquifer widens and groundwater deepens. Streamflow gains occurred in the subreach upstream from the Moore Diversion in 2019, but streamflow losses occurred in the 2020 and 2021 events, coincident with declining regional groundwater levels. These results suggest that changing surface-water supply, irrigation use, and recharge affect interannual groundwater levels and, in turn, affect patterns of streamflow gains and losses in the middle reach. Finally, surface-water management is the primary control on surface-water/groundwater interactions in the lower reach, and substantial streamflow past the Moore Diversion only occurred during the 2019 events. In most subreaches, streamflow gains or losses were small and measurement uncertainty often was greater than the change. However, small streamflow gains near Moore and Arco suggest that groundwater can contribute to streamflow during wet conditions.

Overall patterns of streamflow gains and losses in this study generally were consistent with previous reports. However, paired with the related hydrogeologic framework and water budget, this investigation provides new insights into how hydrogeologic conditions and interannual variability in water supply, groundwater levels, and surface-water management affect surface-water/groundwater interactions in the Big Lost River Valley. 


\section{Introduction}

The Big Lost River Basin is a hydrogeologically unique basin in south-central Idaho located on the northeastern boundary of the Snake River Plain (fig. 1). Distinct areas where the Big Lost River gains or loses substantial streamflow from or to groundwater, hereinafter referred to as gaining or losing reaches, respectively, have long been recognized. The Big Lost River ultimately infiltrates entirely into the subsurface while flowing south and east across the Snake River Plain, thereby contributing recharge to the eastern Snake River Plain aquifer. The last comprehensive study to describe water resources in the basin was done by Crosthwaite and others (1970), who concluded on p. 34 that "Surface and groundwater are so closely related that neither can be considered as a separate source of supply." Surface-water and groundwater resources used for domestic water supply, irrigated agriculture, and ranching are vital for communities and their economies in the Big Lost River Basin. Since 1977, groundwater levels in the Big Lost River Basin have declined because of drought and water use (Sukow, 2017).

The Idaho Department of Water Resources (IDWR) is assigned with managing and administering the water resources of Idaho. With changing groundwater levels and surface-water flows, water resource management is continuously evolving. In 2016, water users in the Big Lost River Basin approached IDWR with concerns about decreasing water resources. They requested the designation of a Critical Ground Water Area (Bernal, 2016) or alternatively, a Ground Water Management Area (Broadie, 2017a, 2017b), to help understand and mitigate the effects of declining water resources. The water users subsequently withdrew their requests but affirmed the need to better understand and manage water resources in the Big Lost River Basin, including connections between surface water and groundwater (Bernal and Broadie, 2017), and established the Big Lost Groundwater District to address concerns over aquifer levels.

In 2019, the U.S. Geological Survey (USGS), in cooperation with the IDWR, began work in the Big Lost River Valley (BLRV) to (1) investigate seasonal streamflow gains and losses in the Big Lost River, (2) help improve hydrologic understanding of river interactions with the underlying aquifer, and (3) provide data to aid in water-management decisionmaking. Moreover, these results will improve water-budget calculations, water-management decisions, IDWR water-right accounting, and representation of the Big Lost River Basin in the Enhanced Snake Plain Aquifer Model (Idaho Department of Water Resources, 2013).

\section{Purpose and Scope}

This report provides estimates of streamflow gains from and losses to groundwater in the Big Lost River between Mackay Reservoir and Arco, Idaho, during four measurement events in March 2019, October 2019, October 2020, and March 2021. This study was done by the USGS in cooperation with the IDWR. This report is the second chapter of a multichapter volume. Zinsser (2021) details the hydrogeological framework of the Big Lost River Basin in the first chapter. The third chapter will describe the water budget in the Big Lost

River Basin by providing annual estimates of aquifer inflows and outflows from 2000 to 2019.

\section{Description of Study Area}

The Big Lost River Basin encompasses about 1,500 square miles with a narrow intermontane basin and surrounding mountain ranges including the Lost River Range, White Knob Mountains, and Pioneer Mountains (fig. 1). Drainage basin altitudes range from 12,667 feet (ft) at Borah Peak to $5,240 \mathrm{ft}$ near Arco, Idaho, at the northeastern boundary of the Snake River Plain with a mean altitude of 7,500 ft (U.S. Geological Survey, 2021a). The study area consists of about 30 miles (mi) of the BLRV, defined here as the part of the valley downstream from Mackay Reservoir to the streamgage near Arco, Idaho (USGS streamgage 13132500, fig.1). The BLRV is dominated by farms and ranches irrigated by groundwater and diverted surface water and includes the incorporated communities of Mackay, Leslie, Darlington, Moore, and Arco. The BLRV downstream from Mackay Reservoir is an alluvial fill valley bounded by ranges on the east and west sides of the valley. Numerous alluvial fans from tributary streams intersect and restrict the valley width, the largest of which are associated with Lower Cedar, Alder, Pass, and Antelope Creeks (fig 1.), although most streamflow infiltrates into the alluvium before connecting to the Big Lost River. A more detailed description of the geology is available in Zinsser (2021). 


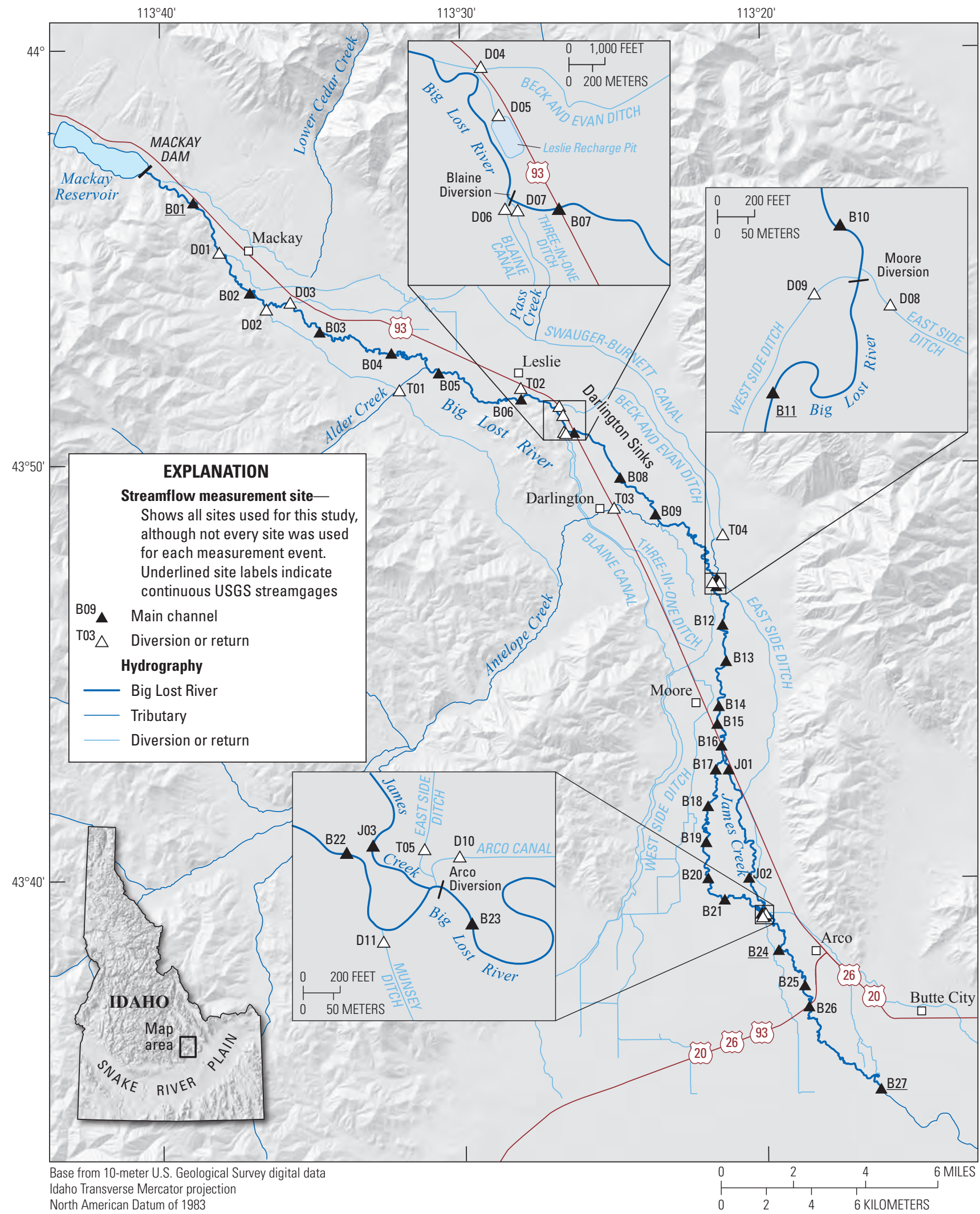

Figure 1. Streamflow measurement sites, communities, and other features in the Big Lost River Basin, south-central Idaho. USGS, U.S. Geological Survey. 
Most precipitation in the Big Lost River Basin falls as snow at high altitudes during the winter months (Clark, 2022) and snowmelt drives streamflow. Mackay Reservoir, operated by the Big Lost River Irrigation District (BLRID), can only store about 20 percent of the average annual flow of the Big Lost River (Crosthwaite and others, 1970). Water stored in the reservoir is released during spring and summer to meet downstream surface-water rights. Winter snowpack and subsequent spring and summer streamflows therefore are critical to water supply in the basin. Mean annual streamflow (water years ${ }^{1} 1948-2020$ ) at Big Lost River below Mackay Reservoir (USGS streamgage 13127000) and Big Lost River near Arco, Idaho (USGS streamgage 13132500) is 313 and 77 cubic feet per second $\left(\mathrm{ft}^{3} / \mathrm{s}\right)$. respectively. Large quantities of water generally only flow past the Big Lost River near Arco, Idaho, streamgage during high streamflow years. During times with abundant water supply, BLRID diverts water to various recharge zones in the BLRV while sustaining a minimum flow of $60 \mathrm{ft}^{3} / \mathrm{s}$ at the Arco streamgage (L. Yocke, Big Lost River Irrigation District, oral commun., 2021). Surface water infiltrates into the underlying aquifer in recharge pits and targeted reaches of the Big Lost River to recharge the aquifer. The largest diversion structures in the BLRV-Blaine Diversion (also locally known as the UC Diversion), Moore Diversion, and Arco Diversion - divert surface water for irrigated croplands and ranches (fig. 1). Groundwater wells are used for irrigation, domestic use, municipal use, and monitoring water levels in the aquifer. The USGS operates four real-time streamgages on the Big Lost River in the BLRV: Big Lost River below Mackay Reservoir (13127000) [B01], Big Lost River below Moore Diversion near Moore, Idaho (13132100) [B11], Big Lost River at Sunset Road at Arco, Idaho (13132373) [B24], and Big Lost River near Arco, Idaho (13132500) [B27] (fig. 1).

\section{Previous Investigations}

The first published streamflow measurements in the BLRV were in 1903 at the streamgage below Mackay Reservoir (13127000). The earliest reports to describe gains and losses in the Big Lost River were focused on improving the efficiency of water delivery for irrigation. In the BLRV, Debler and others (1931) described major losses of water from the Big Lost River in "sinks" near Darlington, below the Moore Diversion, below Arco, and in Antelope Creek above its confluence with the Big Lost River. Debler and others (1931) described irrigation water returns (gains) to the Big Lost River upstream from Mackay and the Moore Diversion, concluding on p. 4 that "waters lost in the Darlington sinks merely pass through the Antelope Creek delta and return in part to the river in the vicinity of the Moore dam [Moore Diversion]." Livingston (1931) attributed surface-water losses

\footnotetext{
${ }^{1}$ The 12-month period from October 1, for any given year, through September 30 of the following year. The water year is designated by the calendar year in which it ends.
}

to increasing valley (aquifer) width and volume and greater porosity associated with fan deposits, and attributed gains to decreased porosity associated with "fanglomerate" (cemented fan deposits). Livingston (1931) further suggested that patterns of rising and sinking surface water were attributable to the uneven topographic gradient intersecting the more regularly sloped groundwater potentiometric surface. Similarly, Stearns and others (1938) attributed gaining and losing reaches in the river to variabilities in the alluvial aquifer geometry but linked these changes to various bedrock outcroppings near Mackay, for example, and near the Moore Diversion.

The last comprehensive hydrogeological investigation in the BLRV was done by the USGS more than 50 years ago. Crosthwaite and others (1970) compiled geological, geophysi$\mathrm{cal}$, and hydrological data to develop a hydrogeologic framework and water budget, and to describe surface-water/groundwater interactions. Pertinent to surface-water/groundwater interactions, Crosthwaite and others (1970) described small streamflow losses and gains depending on river stage between Mackay and Leslie and small streamflow gains upstream from the Moore Diversion, but overall large streamflow losses between Mackay and the Moore Diversion attributable to large losses in the Darlington Sinks. Similarly, they reported overall streamflow losses between the Moore Diversion and the USGS streamgage south of Arco (13132500), notwithstanding small gains in streamflow measured around Arco. The pattern of streamflow gains and losses was attributed to the effects of valley (and, therefore, aquifer) widening and narrowing, changes in alluvial fill permeability, and the quantity of water (Crosthwaite and others, 1970).

More recently, Rice and Boyd (2008) measured Big Lost River streamflow in a series of events from April to November 2007 between Leslie and the Moore Diversion; they estimated large losses through the Darlington Sinks and small gains upstream from the Moore Diversion during various streamflow conditions. They attributed gains and losses to changes in the valley (aquifer) width, aquifer permeability, climate, and irrigation management.

Concurrent with this investigation of surface-water/ groundwater interactions, Clark (2022) estimated a water budget for the Big Lost River Basin spanning 2000-19, and Zinsser (2021) developed an updated hydrogeologic framework to describe groundwater in the basin. Pertinent to this study, Clark (2022) estimated that the single largest annual inflow to the aquifer is losing river reaches, with greater volumes entering the aquifer during years with above-average annual total precipitation. Zinsser (2021) described multiple hydrogeologic controls on surface-water/groundwater interactions. From Mackay through the Darlington Sinks, aquifer geometry, as controlled by valley geometry, exerts the primary control on surface-water gains from and losses to groundwater, and coarsening alluvial fill contributes to streamflow losses through the Darlington Sinks. Historical rising waters upstream from the Moore Diversion and near Arco are driven partly by valley (aquifer) geometry, but also by groundwater 
recharge, surface-water management, and irrigation practices. Gaining streamflows near Arco are also likely influenced by the presence of a subsurface confining unit.

\section{Methods}

\section{Streamflow Measurements}

Surface-water streamflow data were collected during four measurement events (March and October 2019, October 2020, and March 2021) by USGS and IDWR personnel. Streamflow measurements were made at main-stem Big Lost River (B01-B27; fig. 1; table 1) and James Creek sites (J01-J03; fig. 1; table 1), outflows (D01-D11; fig. 1; table 1), and inflows (T01-T05; fig. 1; table 1). Measurement sites were selected based on land access and quality of the cross section. Measurement event dates were selected for periods of high streamflow to capture streamflow farther downstream. Moreover, periods of minimized diversions and groundwater pumping were selected to reduce overall uncertainty in estimates of gains and losses to and from groundwater. Generally, the measurement events occurred in March, before irrigators began diverting water for crops, and in October, after diversions and groundwater pumping were discontinued. During measurement events, the BLRID maintained steady releases from the Mackay Reservoir and minimized changes within the diversion system to assist the study. Sites measured varied somewhat between events because of changing streamflow and diversion conditions, varied landowner access, time constraints, and efforts to improve spatial coverage and reduce uncertainty.

All streamflow measurements were taken and reviewed according to USGS policies and guidelines (Rantz, 1982; Oberg and Mueller, 2007; Mueller and others, 2009; Turnipseed and Sauer, 2010). A Teledyne RD Instruments StreamPro ${ }^{\circledR}$ 2,000-kilohertz acoustic Doppler current profiler (ADCP) was used to measure streamflow at most sites. Alternatively, for sites with insufficient depth and (or) width to use the ADCP, a YSI Sontek FlowTracker or FlowTracker2 handheld acoustic Doppler velocimeters (ADVs) with a top-setting wading rod was used to measure flow. Quality assurance tests of all ADVs and ADCPs were done at the streamgage below Mackay Reservoir (13127000) before each measurement event to ensure that the instruments produced accurate and consistent results and that methods were consistent between staff. Streamflow measurements reported here also are published in the USGS National Water Information System (U.S. Geological Survey, 2021b).

Net streamflow gain or loss was quantified in three reaches, each composed of multiple subreaches, downstream from Mackay Reservoir. The upper reach is a 15.7-mi section of the Big Lost River between USGS streamgage 13127000 below Mackay Reservoir and site 13130300 near Leslie, Idaho. The middle reach constitutes 10.4-mi of the Big Lost River between Leslie, Idaho, and the Moore Diversion and encompasses the Darlington Sinks. The lower reach is 23.9-mi long between the Moore Diversion and USGS streamgage 13132500 near Arco, Idaho.

\section{Calculations of Net Streamflow Gain or Loss}

Synoptic streamflow measurements can be used to determine flow interactions between surface water and groundwater in a river or stream. An increase (gain) or decrease (loss) in streamflow that is not attributed to surface-water inflows or outflows between measurement sites is inferred to indicate groundwater exchange (Riggs, 1972). Long reaches composed of multiple subreaches were used to determine surface-water/ groundwater interactions in the Big Lost River. Net streamflow gain or loss was calculated in three reaches: Mackay to Leslie (upper reach), Leslie to Moore Diversion (middle reach), and Moore Diversion to Arco (lower reach). Streamflow gains and losses are calculated according to the equation (Simonds and Sinclair, 2002):

$$
\text { Net seepage gain or loss }=Q_{d}-I-Q_{u}+O \text {, }
$$

where

$$
\begin{gathered}
Q_{d} \quad \begin{array}{l}
\text { is the streamflow measured at the downstream } \\
\text { end of the reach or subreach, in cubic feet } \\
\text { per second; }
\end{array} \\
\begin{array}{c}
\text { is the streamflow measured at the upstream } \\
\text { end of the reach or subreach, in cubic feet } \\
\text { per second; }
\end{array} \\
\quad \text { is the sum of inflows, in cubic feet per } \\
\text { second; and } \\
\text { is the sum of outflows, in cubic feet } \\
\text { per second. }
\end{gathered}
$$

The result is the net streamflow gain or net streamflow loss from the river. Positive values (gaining reach) indicate movement of water from groundwater to surface water, suggesting a higher groundwater potentiometric surface relative to surface water. Negative values (losing reach) indicate movement of water from surface water to groundwater, suggesting a lower groundwater potentiometric surface relative to surface water. Other sources of loss, such as evaporation, were expected to be negligible during the measurement events because of low temperatures and were not included in calculation of a loss or gain in a subreach or reach. 


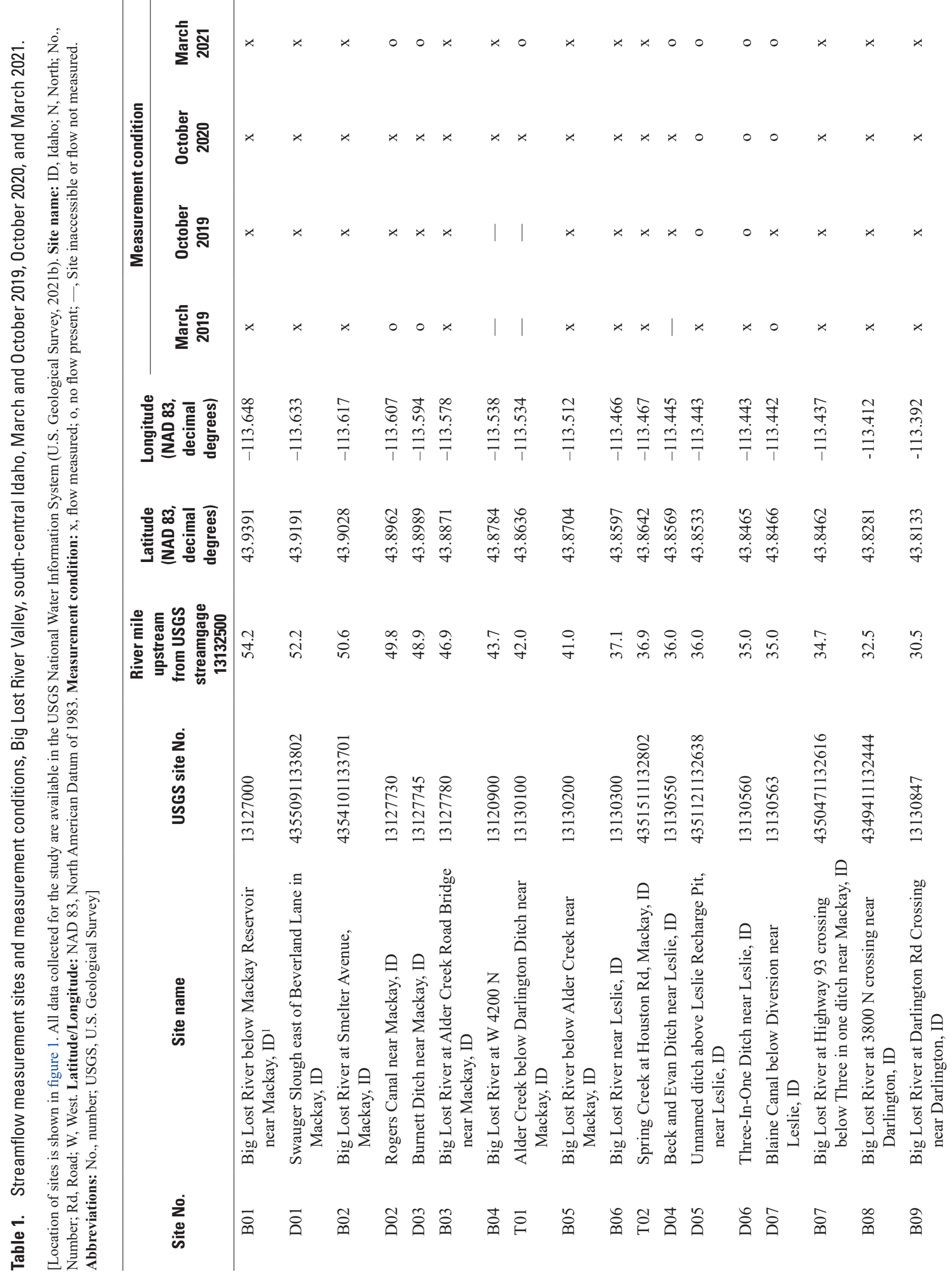




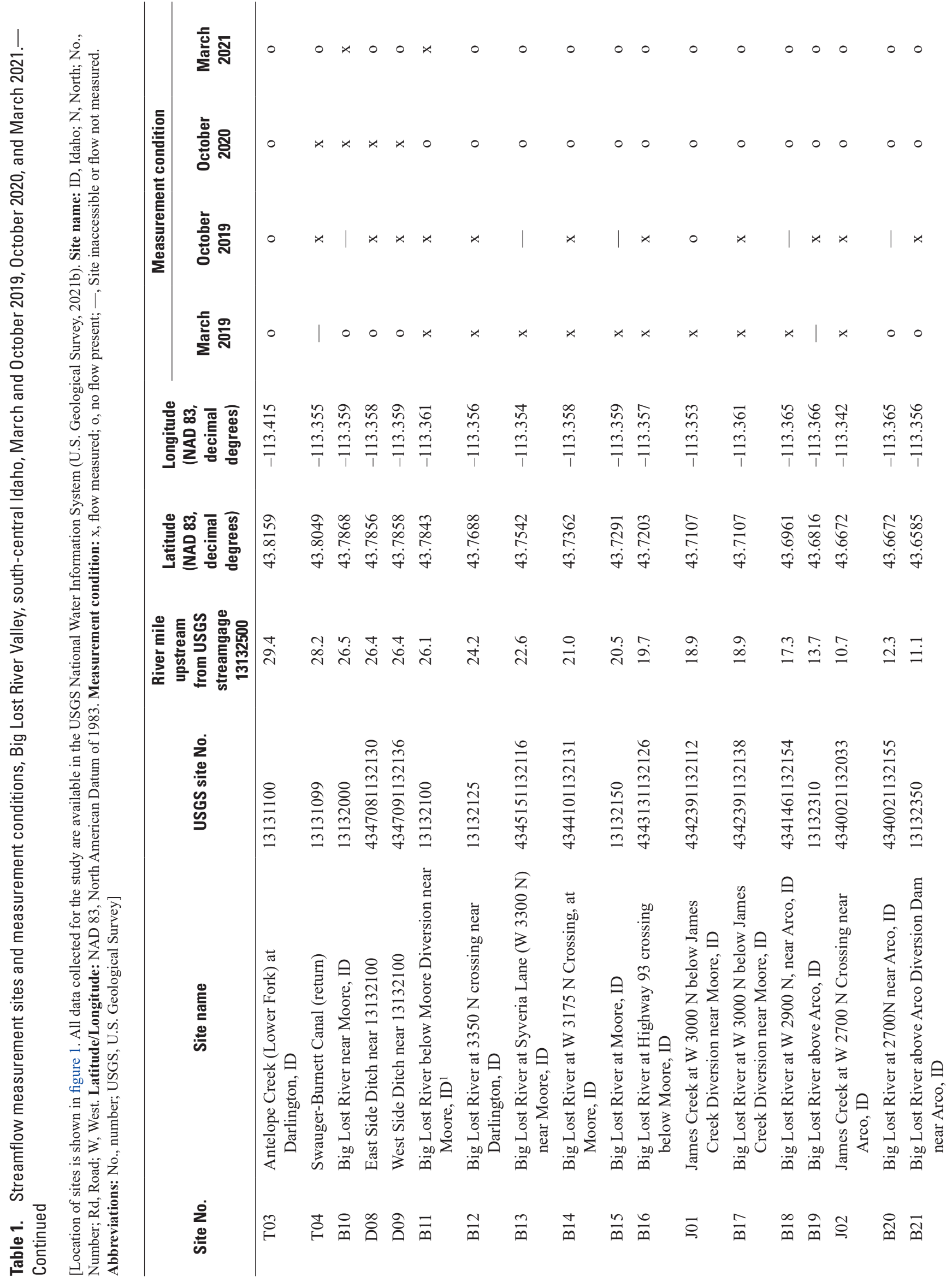




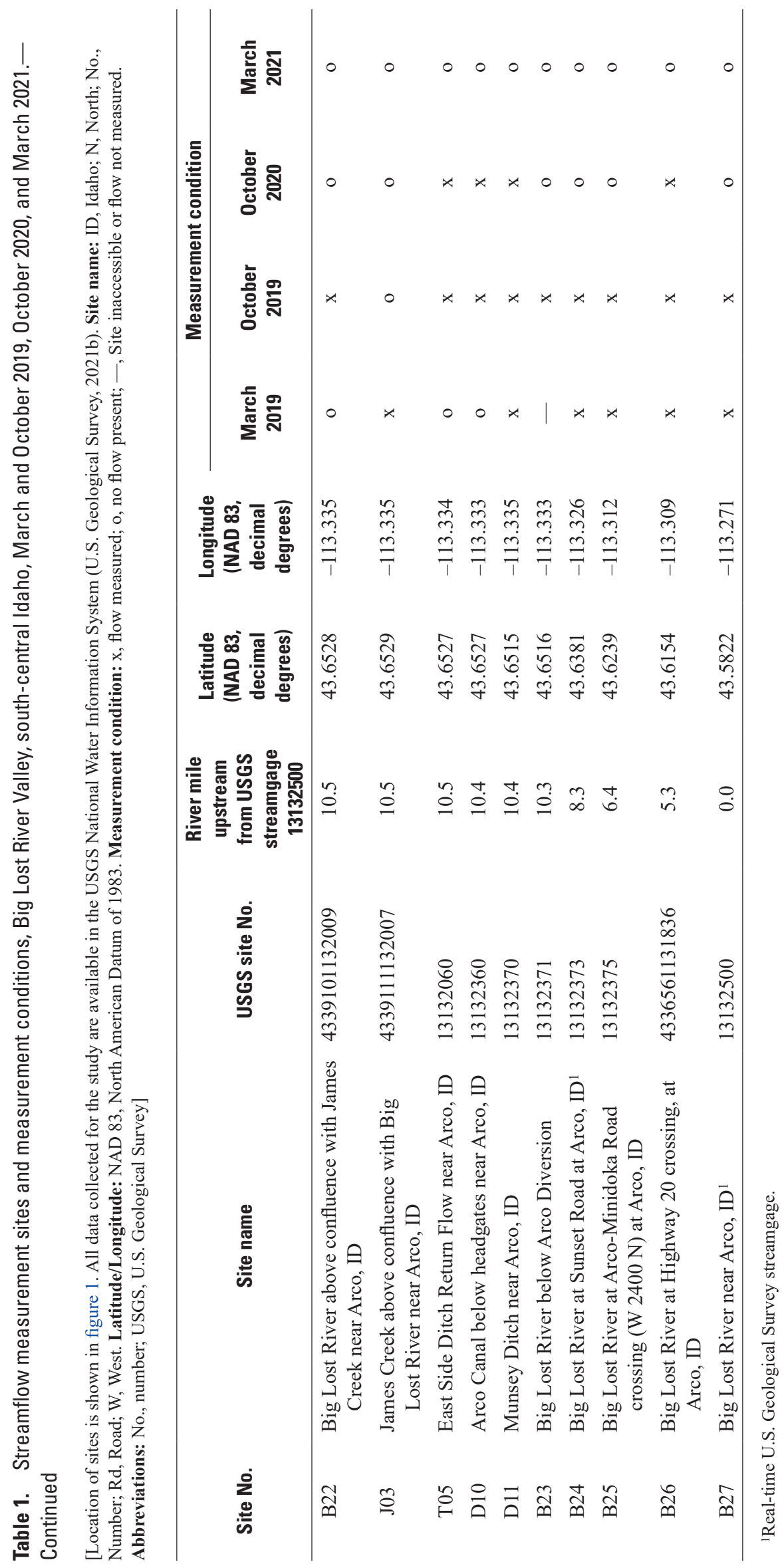




\section{Streamflow Measurement Uncertainty}

Uncertainty represents inherent inaccuracies from equipment and techniques used for measuring streamflow. Streamflow measurement uncertainty is important to characterize in studies that determine a gain or loss of streamflow because small streamflow differences between measurements can be obscured by high measurement uncertainty. Measurement uncertainty for both types of instruments is expressed as a percentage of the total measured streamflow. The SonTek FlowTracker and FlowTracker2 ADVs calculate these uncertainties (STATS and IVE, respectively) within the instrument by accounting for random errors in the depth and velocity during the measurement (Cohn and others, 2013). Uncertainty associated with ADCP measurements was determined in the USGS software program, QRev. The program computes the 95-percent uncertainty level based on random error, invalid data, edge discharge, extrapolation, moving-bed, and any systematic error (Mueller, 2016).

The total estimated uncertainty for a particular subreach is calculated by propagating the uncertainty of each measurement to determine if the cumulative streamflow uncertainty exceeds the net gain or loss within that subreach using an equation adapted from Wheeler and Eddy-Miller (2005):

$$
s=\sqrt{( \pm a)^{2}+( \pm b)^{2} \ldots+( \pm n)^{2}}
$$

where

$s \quad$ is the propagated streamflow uncertainty from all measurement uncertainties, and

$a, b, \ldots, n \quad$ are the estimated streamflow uncertainty from each measurement.

Confidence in this calculation is diminished when the propagated uncertainty for a given reach is greater than the net gain or loss in the subreach. Propagated uncertainty is represented as a plus or minus $( \pm)$.

\section{Groundwater Levels}

IDWR maintains a groundwater-level monitoring network in the Big Lost River Basin. Groundwater-level measurements were collected by hand using manual measurement methods with an electric tape during discrete measurement events and with nearly continuous groundwater-level measurements using pressure transducers and data loggers placed in the wells. Groundwater-level measurements are available on the IDWR website (Idaho Department of Water Resources, 2021). Groundwater altitudes were calculated using the land-surface altitude at the well. However, well altitude and location data vary in quality, and altitude cannot be verified to a common vertical datum, nor were the data collected prior to October 17, 2019, barometrically corrected. Although these issues introduce some uncertainty to groundwater altitudes, these effects are small relative to the overall groundwater altitude change across the valley (more than 1,000 ft).

Groundwater levels from 22 wells in the long-term monitoring network (table 2) were used to generate potentiometric surface-altitude maps during each streamflow-measurement event. IDWR measured groundwater-levels within 1 week of each seepage study; these discrete manual measurements were used to maximize the number of wells represented in the maps. The potentiometric surfaces were kriged in ArcGIS ${ }^{\mathrm{TM}}$ and then refined by hand. Potentiometric surface is used here to be inclusive of confining conditions observed in some parts of the aquifer (Zinsser, 2021).

IDWR installed a series of shallow well clusters at six locations in the Big Lost River Basin during summer 2019. Each well cluster contains three wells, completed to 20-, 40-, and 50- or 60-ft depths. Data from the shallow well clusters were not used to generate the potentiometric surfaces owing to data comparability issues (for example, wells were not installed during the first streamflow measurement event, and some wells were affected by river altitude and thus represent local groundwater conditions rather than the more regional representation of the long-term monitoring wells). However, continuous groundwater-level data from the shallow wells were used to understand vertical gradients near the Big Lost River. 
Table 2. Groundwater-level monitoring wells and potentiometric surface altitudes during surface-water measurement events, Big Lost River Basin, south-central Idaho.

[Groundwater levels collected prior to October 2019 are not barometrically corrected. Name: As assigned by and used in this report. IDWR, Idaho Department of Water Resources. PLSS identifier: Public Land Survey System identifier used by the Idaho Department of Water Resources and based on the township, range, and section of the well. Latitude/Longitude: NAD 83, North American Datum of 1983]

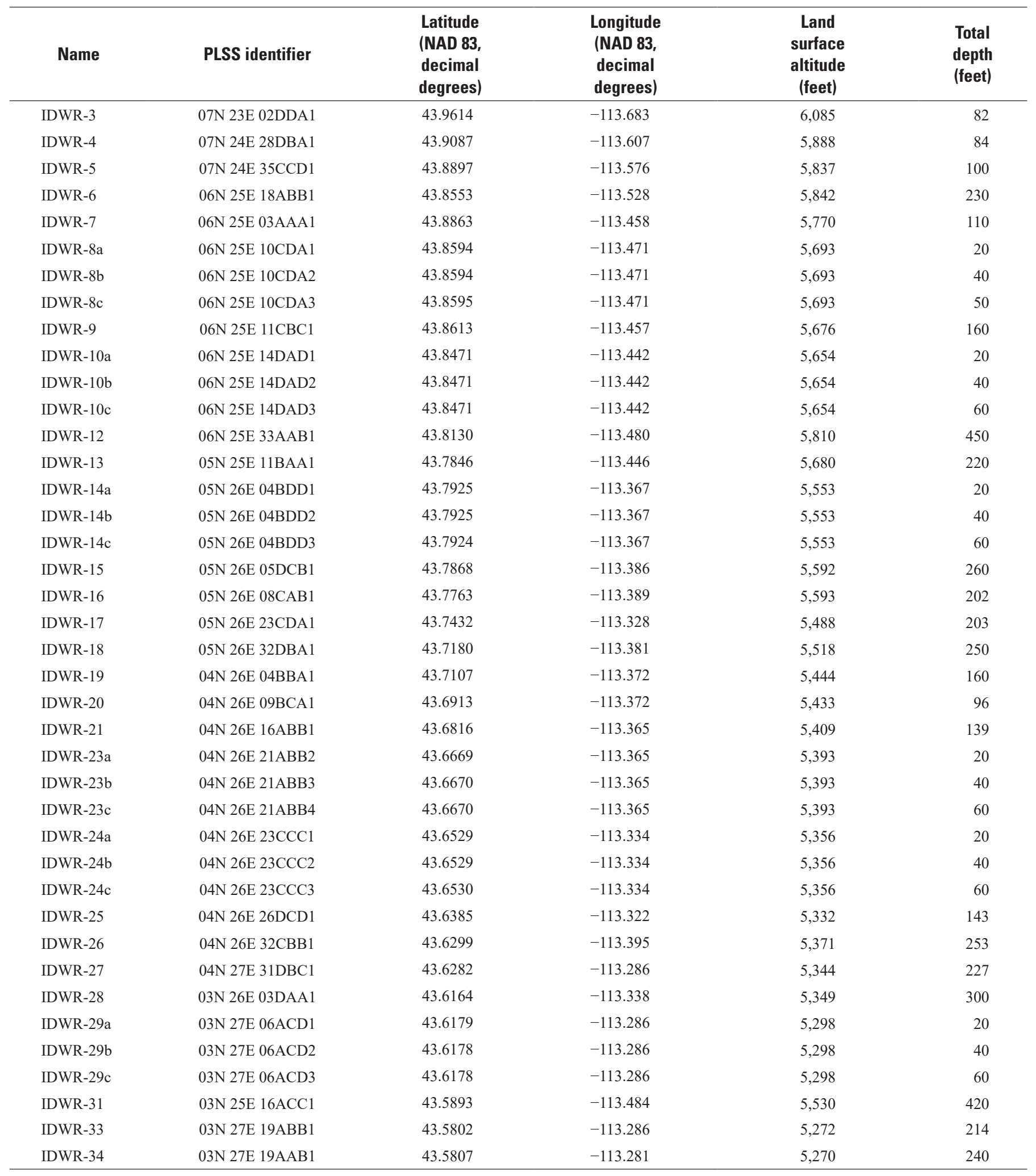




\section{Results for Streamflow Gains and Losses}

\section{March 2019 Measurement Event}

Streamflow measurements were taken during March 27-28, 2019, at 28 sites to determine gains from or losses to groundwater between Mackay Reservoir and Arco, Idaho, with any substantial tributaries and diversions measured along each reach (fig. 2; table 3). Daily mean streamflow below Mackay Reservoir (USGS streamgage 13127000) on March 27 was $203 \mathrm{ft}^{3} / \mathrm{s}$. To prepare for the remaining snowmelt in the upstream basin, water managers increased the outflow from Mackay Reservoir to $220 \mathrm{ft}^{3} / \mathrm{s}$ on March 28, allowing for managed recharge throughout the BLRV. A rain event occurred overnight during the measurement event, contributing to the approximate $15-\mathrm{ft}^{3} / \mathrm{s}$ increase at the streamgage below the Moore Diversion (13132100). To account for changes in upstream streamflow, a gage reading was used at B11 for the first day, and a measurement was made at B11 on the second day. Overall net gain or loss throughout the reach and subreach was calculated using the second-day measurement at B11, resulting in a data gap between B14 and B15.

In the upper reach, net streamflow gains and losses were greater than uncertainty for all subreaches between Mackay and Leslie except B05-B06 (fig. 2). Streamflow gains were measured in subreaches B01-B02 and B03-B05, which contributed to the net gain between Mackay and Leslie of $7.62 \pm 8.67 \mathrm{ft}^{3} / \mathrm{s}$ indicating an elevated groundwater table and discharge to the river as a result (fig. 2; table 3). The largest observed loss in a subreach was measured between B02 and B03. The Big Lost River moves towards the center of the valley and away from the hillside near B02, which may explain the measured loss in that subreach (fig. 2). Swauger Slough (D01) was the only diversion flowing in the reach during the measurement event.

In the middle reach, streamflow measurements indicated a net loss of $41.3 \pm 7.74 \mathrm{ft}^{3} / \mathrm{s}$ despite a single gaining subreach (B09-B11) (fig. 2; table 3). Net streamflow gains and losses greater than uncertainty were measured for each subreach between $\mathrm{B} 06$ and $\mathrm{B} 11$. A net loss in this reach suggests the depth-to-groundwater increases.

In the lower reach, net streamflow losses exceeded measurement uncertainty in five subreaches downstream from B11, but uncertainty exceeded net gain or loss in nine subreaches (fig. 2). Measurements in this reach (B11-B27) indicated a net loss of $39.9 \pm 1.88 \mathrm{ft}^{3} / \mathrm{s}$, similar to the losses in the middle reach (fig. 2; table 3). About 90 percent of the flow was diverted through James Creek, with the remaining 10 percent going through the Big Lost River downstream from Moore near J01 and B17 (table 3). Two losing subreaches on the Big Lost River were measured downstream from the split before the remaining streamflow was lost to groundwater upstream from B20 (fig. 2). The Big Lost River and James Creek split is a self-regulating diversion and splits the streamflow to each channel based on the quantity of water upstream (Lucas Yocke, Big Lost River Irrigation District, oral commun., 2021). The Big Lost River is the preferential channel but prior to the measurement event, Butte County acquired a conditional use permit to divert most of the flow through James Creek to mitigate downstream flooding (Tim Luke, Idaho Department of Water Resources, oral commun., 2021). For each subreach between the Arco Diversion and B27, the small streamflow gain or loss was less than the total propagated measurement uncertainty.

\section{October 2019 Measurement Event}

Streamflow measurements were taken during October 16-17, 2019, at 34 sites to determine gains from or losses to groundwater between Mackay Reservoir and Arco, Idaho, with any substantial tributaries and diversions measured along each reach (fig. 3; table 4). Streamflow conditions in October 2019 generally represent post-irrigation season, with daily mean streamflow of $205 \mathrm{ft}^{3} / \mathrm{s}$ below Mackay Reservoir (USGS streamgage 13127000) and minimal diversions. A repeat streamflow measurement was made at B11 at the start of the second day of measurements to account for any changes in upstream streamflow.

Like the March 2019 results, net streamflow gains and losses measured in the upper reach were greater than uncertainty for all subreaches except B05-B06 because of a poor measurement cross section at B05 (fig. 3). Despite higher streamflows in each diversion during the October 2019 measurement event (D01, D02, D03), comparison with March 2019 measurements show the same gaining (B01-B02, B03-B05) and losing (B02-B03) subreaches. The largest measured streamflow loss during the October 2019 measurement event occurred in the B02-B03 subreach $\left(45.8 \mathrm{ft}^{3} / \mathrm{s}\right)$. Although the gaining and losing subreaches were similar between the 2019 measurement events, the upper reach had an overall net streamflow loss of $12.9 \pm 7.83 \mathrm{ft}^{3} / \mathrm{s}$ between Mackay and Leslie (fig. 3; table 4) in contrast to the overall gain measured in the spring.

In the middle reach, several sites were added in October 2019 to improve accounting for inflows and outflows. Beck and Evan Ditch (D04) and Swauger-Burnett Canal Return (T04) were added, although streamflow at T04 was estimated by IDWR personnel based on visual observation and nearby irrigation streamgages. Big Lost River near Moore, Idaho (B10, which is directly upstream from the Moore Diversion), East Side Ditch (D08), and West Side Ditch (D09, also locally known as the Moore Canal) were added to improve calculations of gains and losses and to decrease propagated uncertainty for the Big Lost River subreach directly upstream from the diversion. 


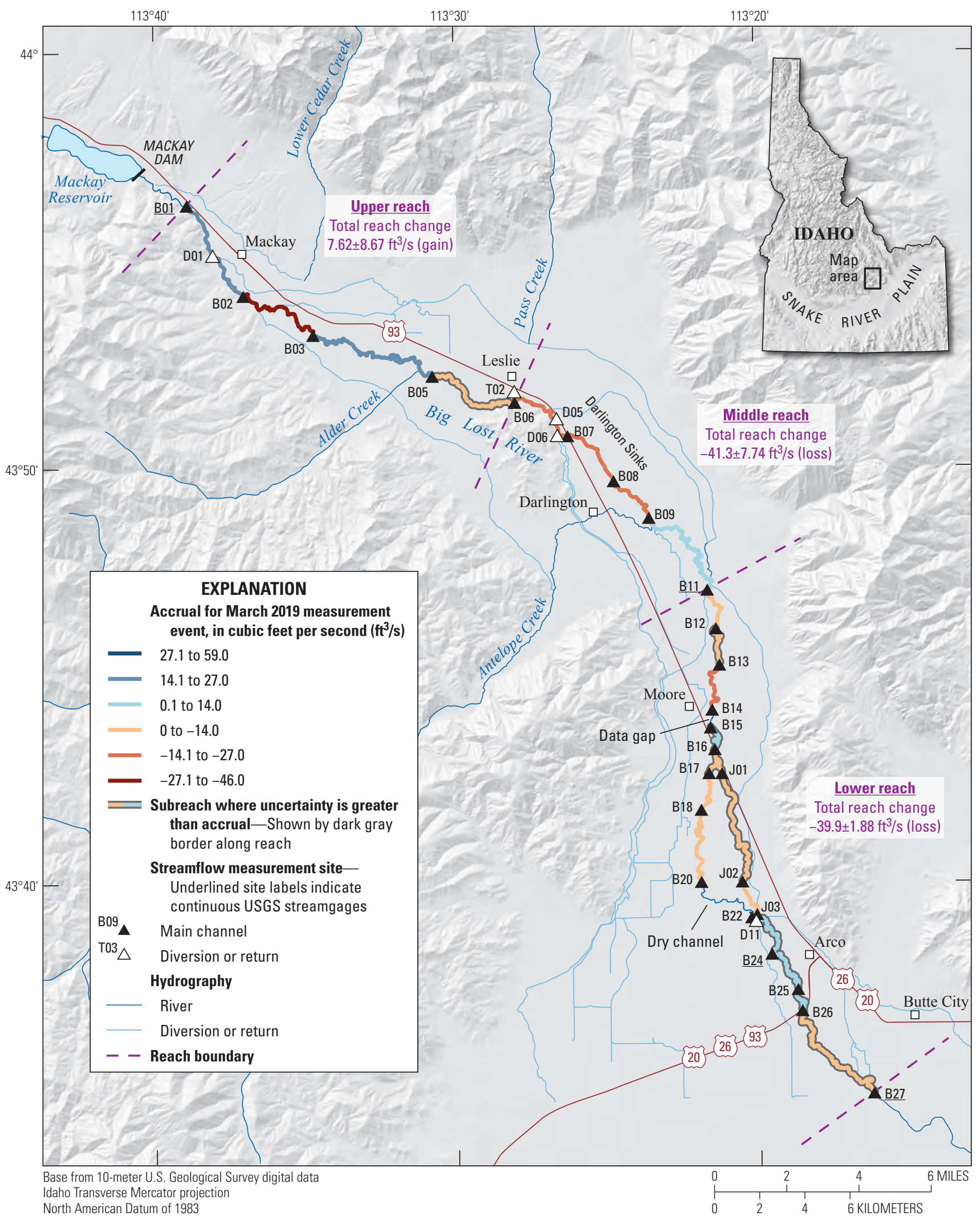

Figure 2. Gaining and losing reaches and subreaches on the Big Lost River, south-central Idaho, March 2019. USGS, U.S. Geological Survey; \pm , plus or minus. 
Table 3. Summary of streamflow, associated estimates of uncertainty, and streamflow gains and losses on measured reaches and subreaches in the Big Lost River Valley, south-central Idaho, March 27-28, 2019.

[Location of sites is shown in figure 1. See table 1 for site names according to river miles. Values at streamgages represent instantaneous measurement rather than daily mean streamflows. Site name: ID, Idaho; N, North; Rd, Road; W, West. Remarks: G, gaining reach; L, losing reach; U, uncertainty of measurements in subreach are greater than measured accrual; Abbreviations and symbols: No., number; $\mathrm{ft} 3 / \mathrm{s}$, cubic feet per second; \pm , plus or minus; —, no data]

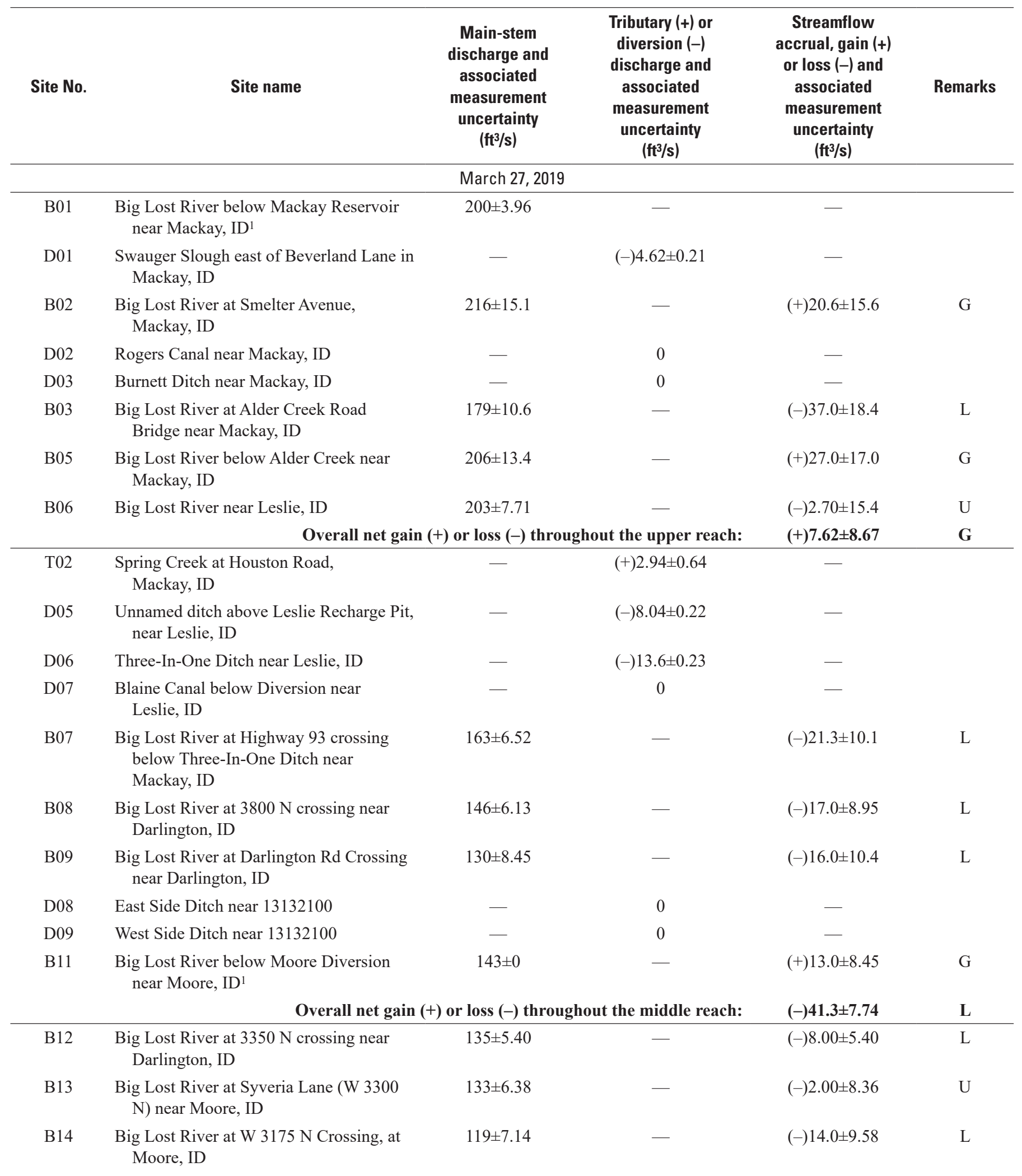


Table 3. Summary of streamflow, associated estimates of uncertainty, and streamflow gains and losses on measured reaches and subreaches in the Big Lost River Valley, south-central Idaho, March 27-28, 2019._-Continued

[Location of sites is shown in figure 1. See table 1 for site names according to river miles. Values at streamgages represent instantaneous measurement rather than daily mean streamflows. Site name: ID, Idaho; N, North; Rd, Road; W, West. Remarks: G, gaining reach; L, losing reach; U, uncertainty of measurements in subreach are greater than measured accrual; Abbreviations and symbols: No., number; $\mathrm{ft}^{3} / \mathrm{s}$, cubic feet per second; \pm , plus or minus; - , no data]

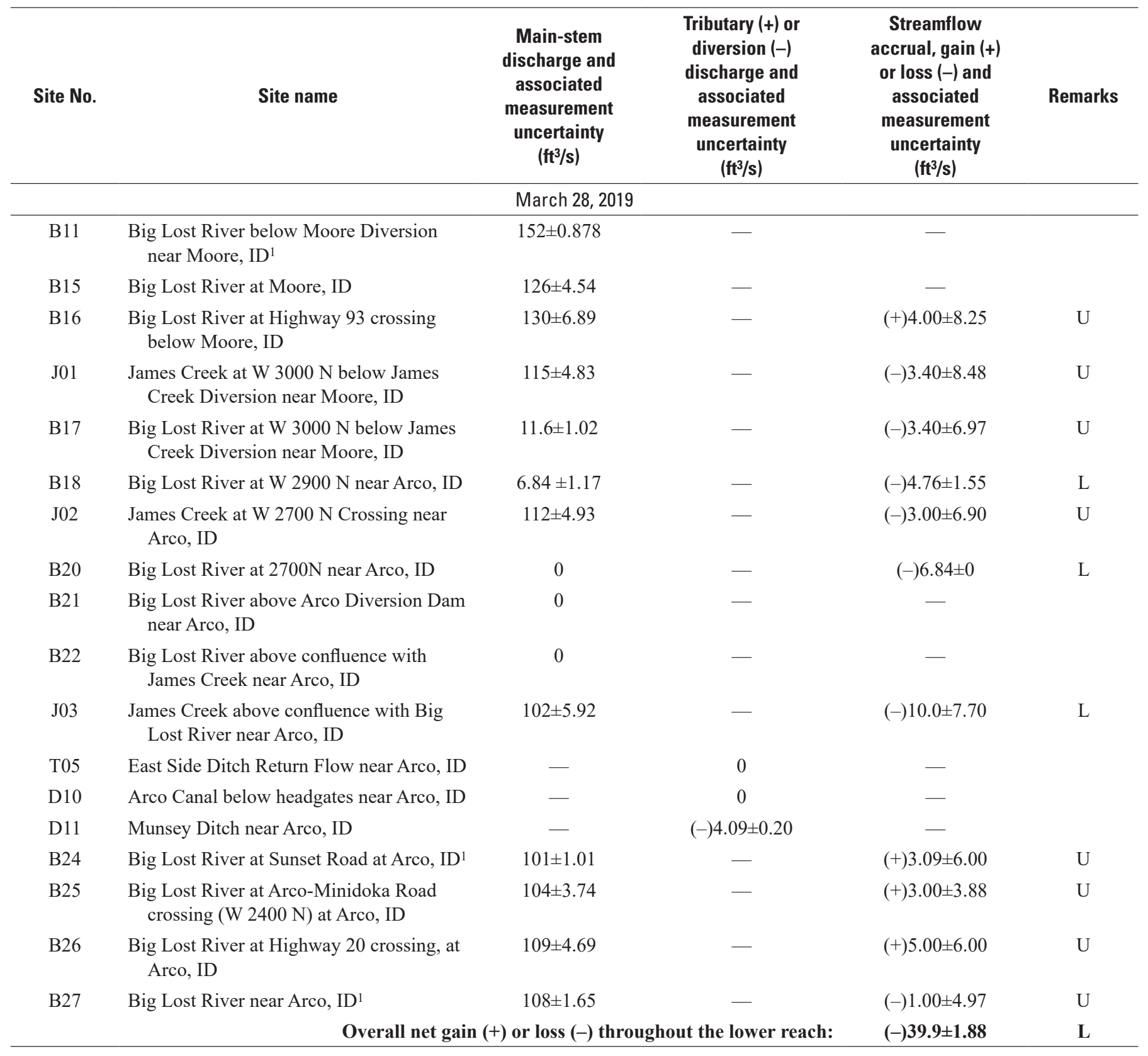

${ }^{1}$ Real-time U.S. Geological Survey streamgage. Measurement uncertainty value equal to 0 indicates that a streamgage reading was used in place of a streamflow measurement. 


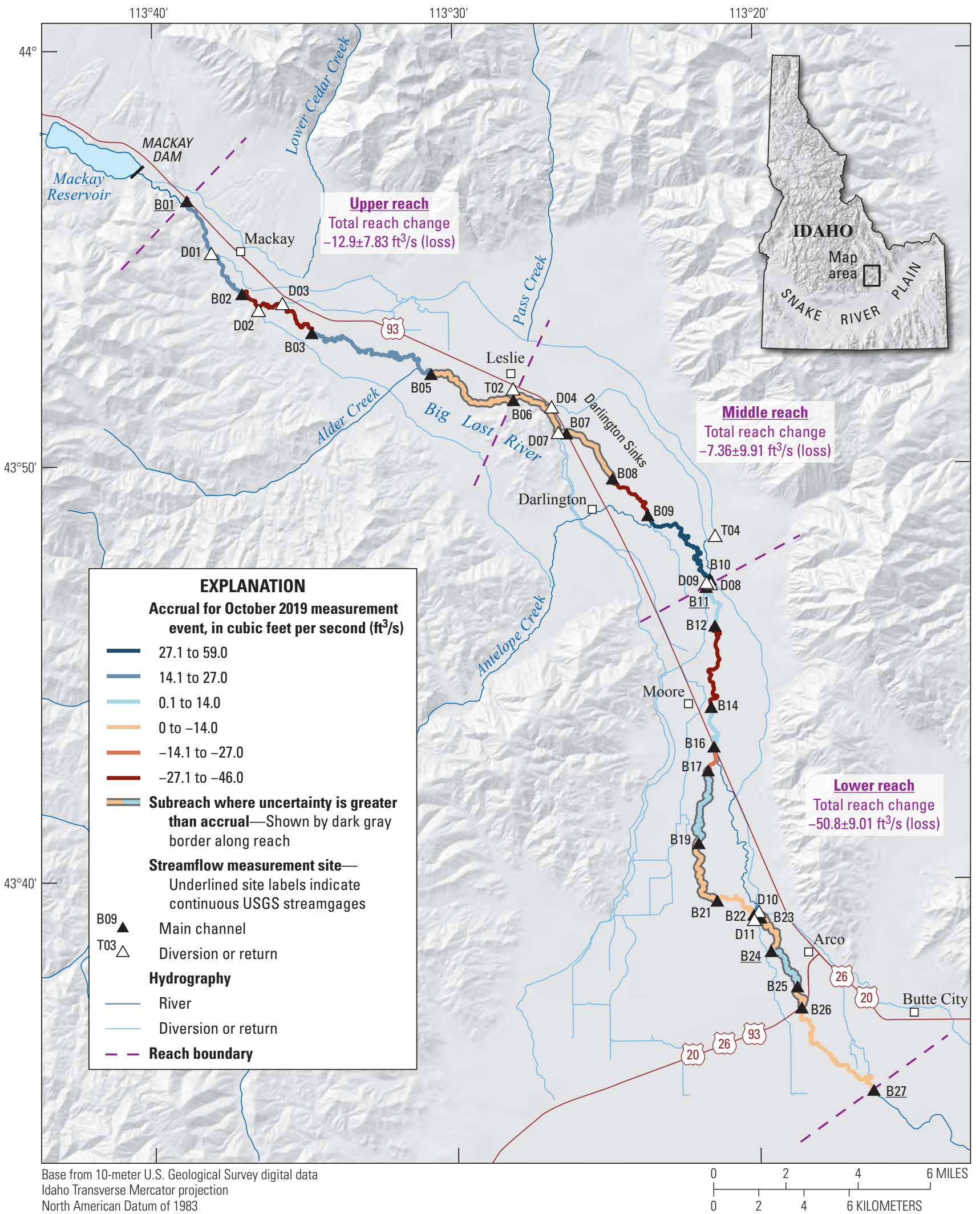

Figure 3. Gaining and losing reaches and subreaches on the Big Lost River, south-central Idaho, October 2019. USGS, U.S. Geological Survey; \pm , plus or minus. 
Table 4. Summary of streamflow, associated estimates of uncertainty, and streamflow gains and losses on measured reaches and subreaches in the Big Lost River Valley, south-central Idaho, October 16-17, 2019.

[Location of sites is shown in figure 1. See table 1 for site names according to river miles. Values at streamgages represent instantaneous measurement rather than daily mean streamflows. Site name: ID, Idaho; N, North; Rd, Road; W, West. Remarks: G, gaining reach; L, losing reach; U, uncertainty of measurements in subreach are greater than measured accrual; Abbreviations and symbols: No., number; $\mathrm{ft}^{3} / \mathrm{s}$, cubic feet per second; \pm , plus or minus; -, no data

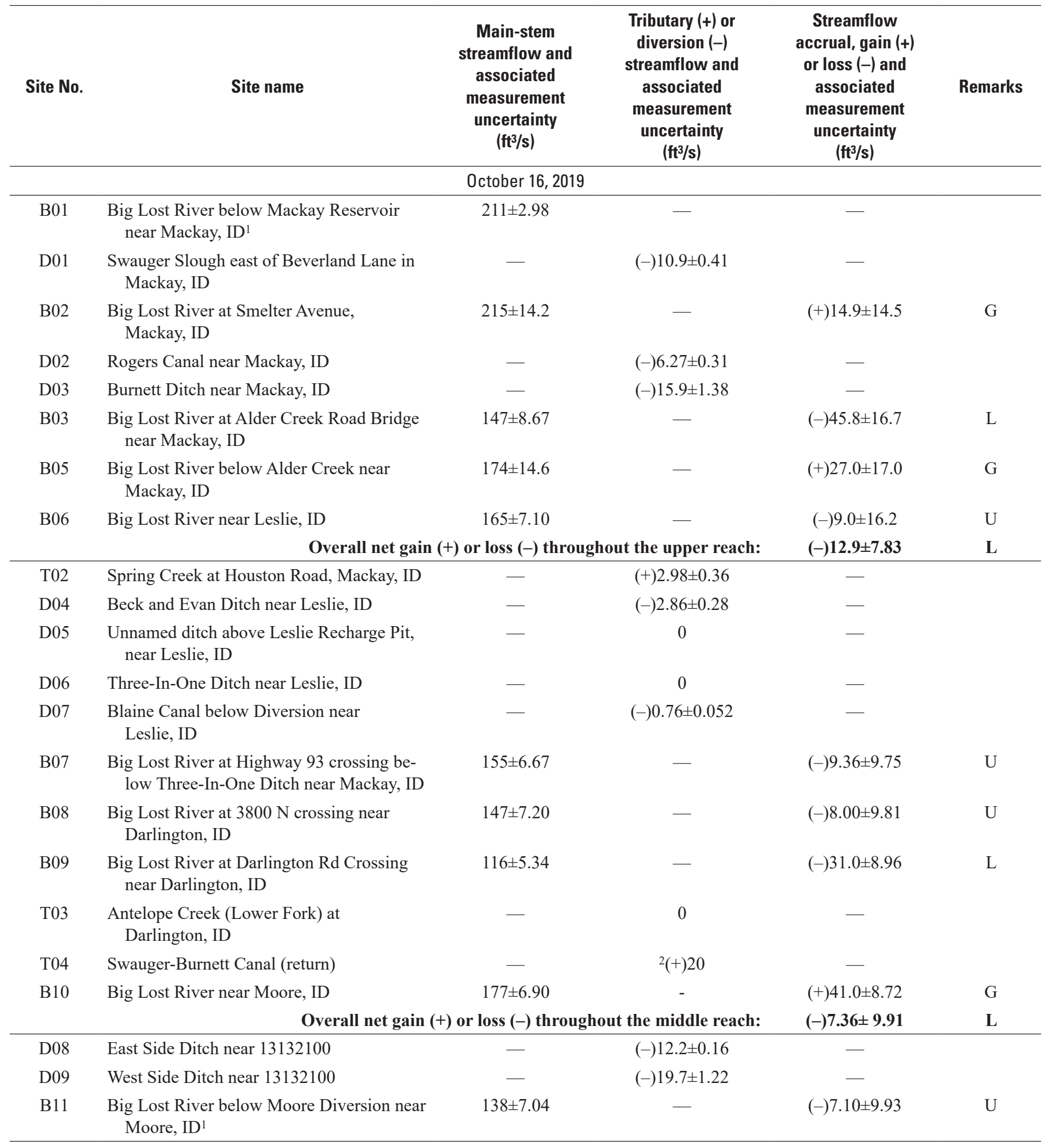


Table 4. Summary of streamflow, associated estimates of uncertainty, and streamflow gains and losses on measured reaches and subreaches in the Big Lost River Valley, south-central Idaho, October 16-17, 2019.—Continued

[Location of sites is shown in figure 1. See table 1 for site names according to river miles. Values at streamgages represent instantaneous measurement rather than daily mean streamflows. Site name: ID, Idaho; N, North; Rd, Road; W, West. Remarks: G, gaining reach; L, losing reach; U, uncertainty of measurements in subreach are greater than measured accrual; Abbreviations and symbols: No., number; $\mathrm{ft} / \mathrm{s}$, cubic feet per second; \pm , plus or minus; - , no data

\begin{tabular}{|c|c|c|c|c|c|}
\hline Site No. & Site name & $\begin{array}{l}\text { Main-stem } \\
\text { streamflow and } \\
\text { associated } \\
\text { measurement } \\
\text { uncertainty } \\
\left(\mathrm{ft}^{3} / \mathrm{s}\right)\end{array}$ & $\begin{array}{l}\text { Tributary }(+) \text { or } \\
\text { diversion }(-) \\
\text { streamflow and } \\
\text { associated } \\
\text { measurement } \\
\text { uncertainty } \\
\left(\mathrm{ft}^{3} / \mathrm{s}\right)\end{array}$ & $\begin{array}{c}\text { Streamflow } \\
\text { accrual, gain (+) } \\
\text { or loss }(-) \text { and } \\
\text { associated } \\
\text { measurement } \\
\text { uncertainty } \\
\left(\mathrm{ft}^{3} / \mathrm{s}\right)\end{array}$ & Remarks \\
\hline \multicolumn{6}{|c|}{ October 17, 2019} \\
\hline B11 & $\begin{array}{l}\text { Big Lost River below Moore Diversion near } \\
\text { Moore, ID }\end{array}$ & $130 \pm 8.84$ & - & - & \\
\hline B12 & $\begin{array}{l}\text { Big Lost River at } 3350 \mathrm{~N} \text { crossing near } \\
\text { Darlington, ID }\end{array}$ & $143 \pm 7.72$ & - & $(+) 13.0 \pm 11.74$ & G \\
\hline B14 & $\begin{array}{l}\text { Big Lost River at W } 3175 \text { N Crossing, at } \\
\text { Moore, ID }\end{array}$ & $105 \pm 5.46$ & - & $(-) 38.0 \pm 9.46$ & $\mathrm{~L}$ \\
\hline B16 & $\begin{array}{l}\text { Big Lost River at Highway } 93 \text { crossing } \\
\text { below Moore, ID }\end{array}$ & $113 \pm 5.09$ & - & $(+) 8.00 \pm 7.27$ & G \\
\hline J01 & $\begin{array}{l}\text { James Creek at W } 3000 \mathrm{~N} \text { below James } \\
\text { Creek Diversion near Moore, ID }\end{array}$ & 0 & - & - & \\
\hline B17 & $\begin{array}{l}\text { Big Lost River at W } 3000 \mathrm{~N} \text { below James } \\
\text { Creek Diversion near Moore, ID }\end{array}$ & $97.7 \pm 3.71$ & - & $(-) 15.3 \pm 6.30$ & $\mathrm{~L}$ \\
\hline B19 & Big Lost River above Arco, ID & $99.2 \pm 6.15$ & - & $(+) 1.50 \pm 7.18$ & $\mathrm{U}$ \\
\hline B21 & $\begin{array}{l}\text { Big Lost River above Arco Diversion Dam } \\
\text { near Arco, ID }\end{array}$ & $97.5 \pm 3.80$ & - & $(-) 1.70 \pm 7.23$ & $\mathrm{U}$ \\
\hline B22 & $\begin{array}{l}\text { Big Lost River above confluence with } \\
\text { James Creek near Arco, ID }\end{array}$ & $89.4 \pm 3.49$ & - & $(-) 8.10 \pm 5.16$ & $\mathrm{~L}$ \\
\hline J03 & $\begin{array}{l}\text { James Creek above confluence with Big } \\
\text { Lost River near Arco, ID }\end{array}$ & - & 0 & - & \\
\hline T05 & East Side Ditch Return Flow near Arco, ID & - & $(+) 2.64 \pm 0.11$ & - & \\
\hline D10 & Arco Canal below headgates near Arco, ID & - & $(-) 6.17 \pm 1.48$ & - & \\
\hline D11 & Munsey Ditch near Arco, ID & - & $(-) 9.89 \pm 0.86$ & - & \\
\hline $\mathrm{B} 23$ & Big Lost River below Arco Diversion & $78.9 \pm 3.23$ & - & $(+) 2.92 \pm 5.06$ & $\mathrm{U}$ \\
\hline B24 & Big Lost River at Sunset Road at Arco, ID 1 & $71.2 \pm 2.92$ & - & $(-) 7.70 \pm 8.35$ & $\mathrm{U}$ \\
\hline B25 & $\begin{array}{l}\text { Big Lost River at Arco-Minidoka Road } \\
\text { crossing (W } 2400 \mathrm{~N} \text { ) at Arco, ID }\end{array}$ & $73.3 \pm 3.01$ & - & $(+) 2.10 \pm 4.19$ & $\mathrm{U}$ \\
\hline B26 & $\begin{array}{l}\text { Big Lost River at Highway } 20 \text { crossing, at } \\
\text { Arco, ID }\end{array}$ & $70.3 \pm 3.30$ & - & $(-) 3.00 \pm 4.47$ & $\mathrm{U}$ \\
\hline \multirow[t]{2}{*}{ B27 } & Big Lost River near Arco, ID ${ }^{1}$ & $65.8 \pm 0$ & - & $(-) 4.50 \pm 3.30$ & $\mathrm{~L}$ \\
\hline & \multicolumn{3}{|c|}{ Overall net gain $(+)$ or loss $(-)$ throughout the lower reach: } & $(-) 50.8 \pm 9.01$ & $\mathbf{L}$ \\
\hline
\end{tabular}

${ }^{1}$ Real-time U.S. Geological Survey streamgage. Measurement uncertainty value equal to 0 indicates that a streamgage reading was used in place of a streamflow measurement.

${ }^{2}$ Value estimated by Idaho Department of Water Resources. 
In the middle reach, propagated measurement uncertainty was greater than measured streamflow losses in the first two subreaches (B06-B07, B07-B08). Similar to the March 2019 measurement event, streamflow loss in the B08-B09 subreach was greater than measurement uncertainty, representing the biggest loss in the middle reach (fig. 3). Streamflow gains greater than measurement uncertainty were observed in the B09-B10 subreach after accounting for inflows from Swauger-Burnett Canal return flow (T04) (table 4). An overall net streamflow loss of $7.36 \pm 9.91 \mathrm{ft}^{3} / \mathrm{s}$ occurred in the middle reach (fig. 3; table 4).

For the lower reach, unlike the March 2019 measurement event, streamflow was measured in the East Side Ditch (D08) and West Side Ditch (D09). Those two measurements contributed to uncertainties greater than measured streamflow loss in the B10-B11 subreach (fig. 3). Although irrigation season was over, East Side Ditch and West Side Ditch were transferring water for groundwater recharge and stock water to downstream users. The largest streamflow loss $\left(-38 \mathrm{ft}^{3} / \mathrm{s}\right.$; table 4) in the lower reach occurred in the B12-B14 subreach. B13 was not measured during the October 2019 measurement event because of time constraints. In contrast to March 2019, James Creek was dry in October 2019, allowing for a better calculation of the loss in the B16-B17 subreach. Small streamflow gains and losses from B19 to B21 were less than the uncertainty. Measurements in the final subreach upstream from the Arco Diversion (B21-B22) indicated a small loss (fig. 3; table 4) that exceeded uncertainty. Uncertainty in measurements exceeded streamflow gains and losses in all subreaches downstream from the Arco Diversion except for the loss in the B26-B27 subreach. Despite the uncertainty associated with each subreach in the lower reach, the net streamflow loss during the October 2019 measurement event was $50.8 \pm 9.01 \mathrm{ft} 3 / \mathrm{s}$, similar in magnitude to the March 2019 measurement event (fig. 3; table 4).

\section{October 2020 Measurement Event}

Streamflow measurements were taken during October 6-7, 2020, at 23 sites for determination of streamflow gains from and losses to groundwater between Mackay Reservoir and Arco, Idaho, with any substantial tributaries and diversions measured along each reach (fig. 4; table 5). Daily mean streamflow was $268-271 \mathrm{ft}^{3} / \mathrm{s}$ below Mackay Reservoir (USGS streamgage 13127000). Although the streamflow was higher at B01 than in previous measurement events, fewer measurements were possible on the Big Lost River downstream from Moore Diversion (fig. 4) because of more diversions. The measurement event was earlier in October 2020 than in October 2019, while more diversions were operating, in anticipation of minimal streamflow releases from the Mackay Reservoir after irrigation season because of the low water year.
In the upper reach, despite an additional measurement site (B04) and higher streamflow in the diversions, uncertainties were higher than streamflow gains or losses for all subreaches between Mackay and Leslie during the October 2020 measurement event (fig. 4). Although the uncertainties were high, small gains and losses contributed to a net overall loss of $10.6 \pm 14.0 \mathrm{ft}^{3} / \mathrm{s}$ in the upstream reach, which was similar in magnitude to the October 2019 measurement event (fig. 4; table 5).

In the middle reach, streamflow losses were greater than measurement uncertainty in each subreach (fig. 4). One operating diversion from the Big Lost River was observed immediately downstream from B08, although the flow rate seemed small (less than $1 \mathrm{ft}^{3} / \mathrm{s}$ ) and no measurement could be taken at the site because of lack of access. Measurements in the B09-B10 subreach showed a loss $\left(22.1 \pm 4.56 \mathrm{ft}^{3} / \mathrm{s}\right)$ instead of a gain as observed in previous measurement events (figs. 2-4). In total, about 42 percent of the total stream flow, or $85.3 \pm 14.6$ $\mathrm{ft}^{3} / \mathrm{s}$, was lost in the middle reach (fig. 4; table 5).

Although the Big Lost River was dry downstream from the Moore Diversion, about 31 percent of the remaining streamflow in the Big Lost River $\left(37.5 \mathrm{ft}^{3} / \mathrm{s}\right)$ was diverted through the East Side Ditch and about 69 percent $\left(83.4 \mathrm{ft}^{3} / \mathrm{s}\right)$ was diverted through the West Side Ditch (table 5). The remaining length of the Big Lost River (B11-B22) and James Creek (J01-J03) was dry during the measurement event, with occasional subreaches containing ponded water and no measurable streamflow. Streamflow measurements were made at the Arco Diversion (table 5) in the East Side Return (T05), Arco Canal (D10), and Munsey Ditch (D11) but because no streamflow occurred in the Big Lost River, no gains or losses could be calculated.

\section{March 2021 Measurement Event}

Streamflow measurements were taken on March 30, 2021, at 14 sites for determination of streamflow gains from or losses to groundwater between Mackay Reservoir and Arco, Idaho, with any substantial tributaries and diversions measured along each reach (fig. 5; table 6). Daily mean streamflow was $108 \mathrm{ft}^{3} / \mathrm{s}$ below Mackay Reservoir (USGS streamgage 13127000). Streamflow at B01 was lowest during March 2021 compared to previous measurement events and consequently fewer measurements were taken on the Big Lost River. Streamflow conditions generally represent pre-irrigation season, with one active diversion (D01) to deliver stock water. Overall, below-average snowpack and low storage in Mackay Reservoir (Natural Resources Conservation Service, 2021a) contributed to the lower streamflows in the Big Lost River during the March 2021 measurement event compared to previous events. 


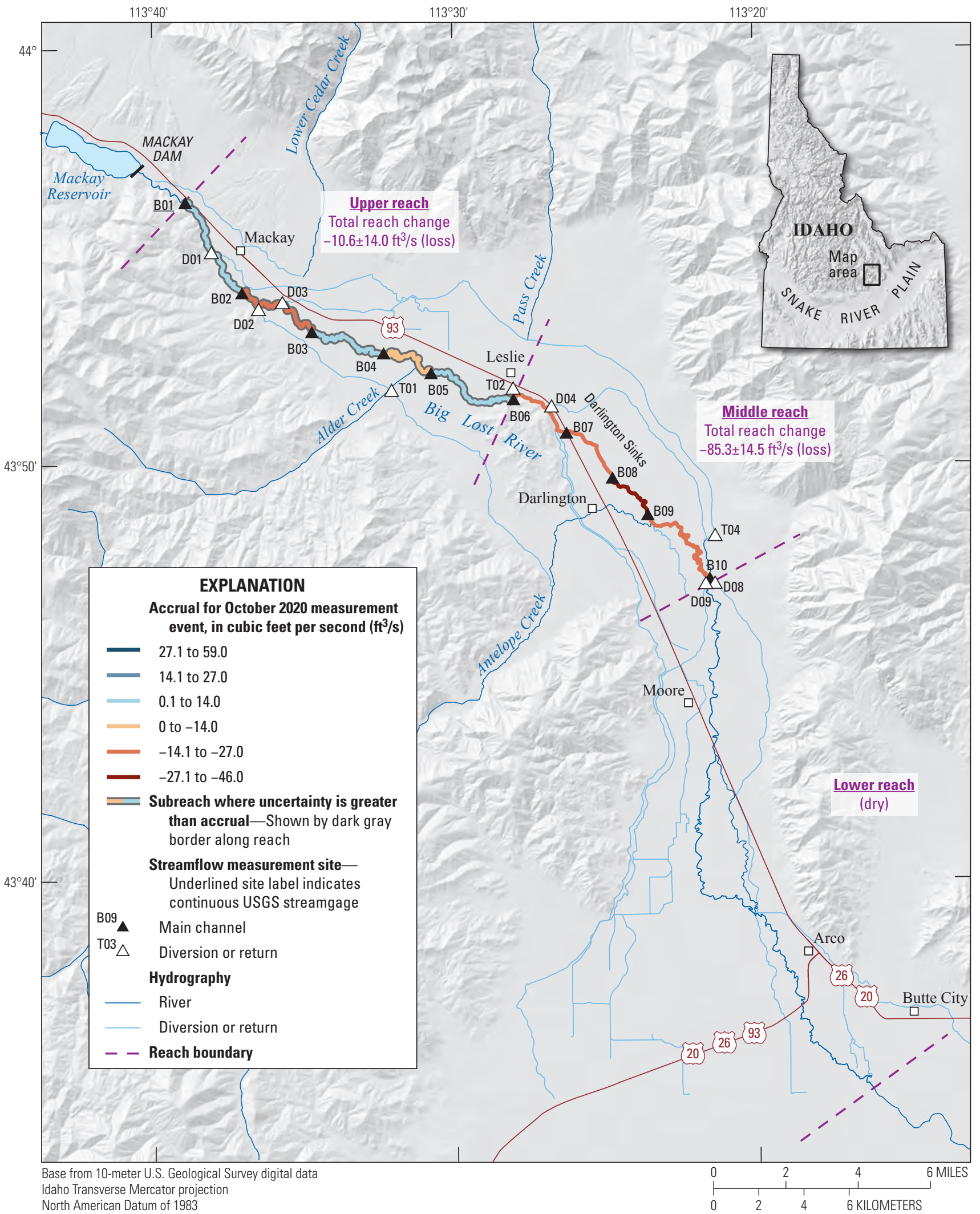

Figure 4. Gaining and losing reaches and subreaches on the Big Lost River, south-central Idaho, October 2020. USGS, U.S. Geological Survey; \pm , plus or minus. 
Table 5. Summary of streamflow, associated estimates of uncertainty, and streamflow gains and losses on measured reaches and subreaches in the Big Lost River Valley, south-central Idaho, October 6-7, 2020.

[Location of sites is shown in figure 1. See table 1 for site names according to river miles. Values at streamgages represent instantaneous measurement rather than daily mean streamflows. Site name: ID, Idaho; N, North; Rd, Road; W, West. Remarks: G, gaining reach; L, losing reach; U, uncertainty of measurements in subreach are greater than measured accrual; Abbreviations and symbols: No., number; $\mathrm{ft}^{3} / \mathrm{s}$, cubic feet per second; \pm , plus or minus; -, no data]

\begin{tabular}{|c|c|c|c|c|c|}
\hline Site No. & Site name & $\begin{array}{l}\text { Main-stem } \\
\text { streamflow and } \\
\text { associated } \\
\text { measurement } \\
\text { uncertainty } \\
\left(\mathrm{ft}^{3} / \mathrm{s}\right)\end{array}$ & $\begin{array}{c}\text { Tributary (+) or } \\
\text { diversion (-) } \\
\text { streamflow and } \\
\text { associated } \\
\text { measurement } \\
\text { uncertainty } \\
\left(\mathrm{ft}^{3} / \mathrm{s}\right)\end{array}$ & $\begin{array}{c}\text { Streamflow } \\
\text { accrual, gain (+) } \\
\text { or loss }(-) \text { and } \\
\text { associated } \\
\text { measurement } \\
\text { uncertainty } \\
\left(\mathrm{ft}^{3} / \mathrm{s}\right)\end{array}$ & Remarks \\
\hline \multicolumn{6}{|c|}{ October 6, 2020} \\
\hline B01 & $\begin{array}{l}\text { Big Lost River below Mackay Reservoir } \\
\text { near Mackay, ID }{ }^{1}\end{array}$ & $271 \pm 0$ & - & - & \\
\hline D01 & $\begin{array}{l}\text { Swauger Slough east of Beverland Lane } \\
\text { in Mackay, ID }\end{array}$ & - & $(-) 17.0 \pm 0.48$ & - & \\
\hline B02 & $\begin{array}{l}\text { Big Lost River at Smelter Avenue, } \\
\text { Mackay, ID }\end{array}$ & $263 \pm 17.9$ & - & $(+) 9.0 \pm 17.9$ & $\mathrm{U}$ \\
\hline D02 & Rogers Canal near Mackay, ID & - & $(-) 31.7 \pm 1.74$ & - & \\
\hline D03 & Burnett Ditch near Mackay, ID & - & $(-) 10.7 \pm 0.26$ & - & \\
\hline B03 & $\begin{array}{l}\text { Big Lost River at Alder Creek Road } \\
\text { Bridge near Mackay, ID }\end{array}$ & $201 \pm 10.5$ & - & $(-) 19.6 \pm 20.8$ & $\mathrm{U}$ \\
\hline B04 & Big Lost River at W $4200 \mathrm{~N}$ & $205 \pm 9.2$ & - & $(+) 4.0 \pm 13.9$ & $\mathrm{U}$ \\
\hline T01 & $\begin{array}{l}\text { Alder Creek below Darlington Ditch near } \\
\text { Mackay, ID }\end{array}$ & - & $(+) 0.99 \pm 0.10$ & - & \\
\hline B05 & $\begin{array}{l}\text { Big Lost River below Alder Creek near } \\
\text { Mackay, ID }\end{array}$ & $201 \pm 8.24$ & - & $(-) 4.99 \pm 12.4$ & U \\
\hline B06 & Big Lost River near Leslie, ID & $202 \pm 13.9$ & - & $(+) 1.00 \pm 16.2$ & $\mathrm{U}$ \\
\hline \multicolumn{4}{|c|}{ Overall net gain $(+)$ or loss $(-)$ throughout the upper reach: } & $(-) 10.6 \pm 14.0$ & $\mathbf{L}$ \\
\hline T02 & $\begin{array}{l}\text { Spring Creek at Houston Road, } \\
\text { Mackay, ID }\end{array}$ & - & $(+) 2.08 \pm 1.15$ & - & \\
\hline D04 & Beck and Evan Ditch near Leslie, ID & - & $(-) 2.84 \pm 0.06$ & - & \\
\hline D05 & $\begin{array}{l}\text { Unnamed ditch above Leslie Recharge } \\
\text { Pit, near Leslie, ID }\end{array}$ & - & 0 & - & \\
\hline D06 & Three-In-One Ditch near Leslie, ID & - & 0 & - & \\
\hline D07 & $\begin{array}{l}\text { Blaine Canal below Diversion near } \\
\text { Leslie, ID }\end{array}$ & - & 0 & - & \\
\hline B07 & $\begin{array}{l}\text { Big Lost River at Highway } 93 \text { cross- } \\
\text { ing below Three-In-One Ditch near } \\
\text { Mackay, ID }\end{array}$ & $183 \pm 6.41$ & - & $(-) 18.2 \pm 15.4$ & $\mathrm{~L}$ \\
\hline B08 & $\begin{array}{l}\text { Big Lost River at } 3800 \mathrm{~N} \text { crossing near } \\
\text { Darlington, ID }\end{array}$ & $167 \pm 11.9$ & - & $(-) 16.0 \pm 13.5$ & $\mathrm{~L}$ \\
\hline B09 & $\begin{array}{l}\text { Big Lost River at Darlington Rd Crossing } \\
\text { near Darlington, ID }\end{array}$ & $138 \pm 2.07$ & - & $(-) 28.9 \pm 12.0$ & $\mathrm{~L}$ \\
\hline T03 & $\begin{array}{l}\text { Antelope Creek (Lower Fork) at } \\
\text { Darlington, ID }\end{array}$ & - & 0 & - & \\
\hline T04 & Swauger-Burnett Canal (return) & - & $(+) 0.08 \pm 0.02$ & - & \\
\hline B10 & Big Lost River nr Moore, ID & $116 \pm 4.06$ & - & $(-) 22.1 \pm 4.56$ & $\mathrm{~L}$ \\
\hline \multicolumn{4}{|c|}{ Overall net gain $(+)$ or loss $(-)$ throughout the middle reach: } & $(-) 85.3 \pm 14.5$ & $\mathbf{L}$ \\
\hline
\end{tabular}


Table 5. Summary of streamflow, associated estimates of uncertainty, and streamflow gains and losses on measured reaches and subreaches in the Big Lost River Valley, south-central Idaho, October 6-7, 2020.-Continued

[Location of sites is shown in figure 1. See table 1 for site names according to river miles. Values at streamgages represent instantaneous measurement rather than daily mean streamflows. Site name: ID, Idaho; N, North; Rd, Road; W, West. Remarks: G, gaining reach; L, losing reach; U, uncertainty of measurements in subreach are greater than measured accrual; Abbreviations and symbols: No., number; $\mathrm{ft}^{3} / \mathrm{s}$, cubic feet per second; \pm , plus or minus; - , no data]

\begin{tabular}{|c|c|c|c|c|c|}
\hline Site No. & Site name & $\begin{array}{c}\text { Main-stem } \\
\text { streamflow and } \\
\text { associated } \\
\text { measurement } \\
\text { uncertainty } \\
\left(\mathrm{ft}^{3} / \mathrm{s}\right)\end{array}$ & $\begin{array}{c}\text { Tributary (+) or } \\
\text { diversion (-) } \\
\text { streamflow and } \\
\text { associated } \\
\text { measurement } \\
\text { uncertainty } \\
\left(\mathrm{ft}^{3} / \mathrm{s}\right)\end{array}$ & $\begin{array}{c}\text { Streamflow } \\
\text { accrual, gain (+) } \\
\text { or loss }(-) \text { and } \\
\text { associated } \\
\text { measurement } \\
\text { uncertainty } \\
\left(\mathrm{ft}^{3} / \mathrm{s}\right)\end{array}$ & Remarks \\
\hline \multicolumn{6}{|c|}{ October 6, 2020-Continued } \\
\hline D08 & East Side Ditch near 13132100 & - & $(-) 37.5 \pm 0.41$ & - & \\
\hline D09 & West Side Ditch near 13132100 & - & $(-) 83.4 \pm 2.92$ & - & \\
\hline B11 & $\begin{array}{l}\text { Big Lost River below Moore Diversion } \\
\text { near Moore, ID }\end{array}$ & 0 & - & - & \\
\hline \multicolumn{6}{|c|}{ October 7, 2020} \\
\hline B12 & $\begin{array}{l}\text { Big Lost River at } 3350 \mathrm{~N} \text { crossing near } \\
\text { Darlington, ID }\end{array}$ & 0 & - & - & \\
\hline B13 & $\begin{array}{l}\text { Big Lost River at Syveria Lane (W } 3300 \\
\text { N) near Moore, ID }\end{array}$ & 0 & - & - & \\
\hline B14 & $\begin{array}{l}\text { Big Lost River at W } 3175 \text { N Crossing, at } \\
\text { Moore, ID }\end{array}$ & 0 & - & - & \\
\hline B15 & Big Lost River at Moore, ID & 0 & - & - & \\
\hline B16 & $\begin{array}{l}\text { Big Lost River at Highway } 93 \text { crossing } \\
\text { below Moore, ID }\end{array}$ & 0 & - & - & \\
\hline $\mathrm{J} 01$ & $\begin{array}{l}\text { James Creek at W } 3000 \mathrm{~N} \text { below James } \\
\text { Creek Diversion near Moore, ID }\end{array}$ & 0 & - & - & \\
\hline B17 & $\begin{array}{l}\text { Big Lost River at W } 3000 \mathrm{~N} \text { below James } \\
\text { Creek Diversion near Moore, ID }\end{array}$ & 0 & - & - & \\
\hline B18 & $\begin{array}{l}\text { Big Lost River at W } 2900 \text { N, near } \\
\text { Arco, ID }\end{array}$ & 0 & - & - & \\
\hline B19 & Big Lost River above Arco, ID & 0 & - & - & \\
\hline J02 & $\begin{array}{l}\text { James Creek at W } 2700 \text { N Crossing near } \\
\text { Arco, ID }\end{array}$ & 0 & - & - & \\
\hline B20 & Big Lost River at $2700 \mathrm{~N}$ near Arco, ID & 0 & - & - & \\
\hline B21 & $\begin{array}{l}\text { Big Lost River above Arco Diversion } \\
\text { Dam near Arco, ID }\end{array}$ & 0 & - & - & \\
\hline B22 & $\begin{array}{l}\text { Big Lost River above confluence with } \\
\text { James Creek near Arco, ID }\end{array}$ & 0 & - & - & \\
\hline J03 & $\begin{array}{l}\text { James Creek above confluence with Big } \\
\text { Lost River near Arco, ID }\end{array}$ & 0 & 0 & - & \\
\hline T05 & $\begin{array}{l}\text { East Side Ditch Return Flow near } \\
\text { Arco, ID }\end{array}$ & - & $(+) 14.5 \pm 1.33$ & - & \\
\hline D10 & $\begin{array}{l}\text { Arco Canal below headgates near } \\
\text { Arco, ID }\end{array}$ & - & $(-) 5.45 \pm 0.36$ & - & \\
\hline D11 & Munsey Ditch near Arco, ID & - & $(-) 11.5 \pm 0.21$ & - & \\
\hline B23 & Big Lost River below Arco Diversion & 0 & - & - & \\
\hline B24 & $\begin{array}{l}\text { Big Lost River at Sunset Road at } \\
\text { Arco, ID }{ }^{1}\end{array}$ & 0 & - & - & \\
\hline
\end{tabular}


Table 5. Summary of streamflow, associated estimates of uncertainty, and streamflow gains and losses on measured reaches and subreaches in the Big Lost River Valley, south-central Idaho, October 6-7, 2020.-Continued

[Location of sites is shown in figure 1. See table 1 for site names according to river miles. Values at streamgages represent instantaneous measurement rather than daily mean streamflows. Site name: ID, Idaho; N, North; Rd, Road; W, West. Remarks: G, gaining reach; L, losing reach; U, uncertainty of measurements in subreach are greater than measured accrual; Abbreviations and symbols: No., number; $\mathrm{ft}^{3} / \mathrm{s}$, cubic feet per second; \pm , plus or minus; -, no data]

\begin{tabular}{|c|c|c|c|c|c|}
\hline Site No. & Site name & $\begin{array}{c}\text { Main-stem } \\
\text { streamflow and } \\
\text { associated } \\
\text { measurement } \\
\text { uncertainty } \\
\left(\mathrm{ft}^{3} / \mathrm{s}\right)\end{array}$ & $\begin{array}{c}\text { Tributary (+) or } \\
\text { diversion (-) } \\
\text { streamflow and } \\
\text { associated } \\
\text { measurement } \\
\text { uncertainty } \\
\left(\mathrm{ft}^{3} / \mathrm{s}\right)\end{array}$ & $\begin{array}{c}\text { Streamflow } \\
\text { accrual, gain (+) } \\
\text { or loss }(-) \text { and } \\
\text { associated } \\
\text { measurement } \\
\text { uncertainty } \\
\left(\mathrm{ft}^{3} / \mathrm{s}\right)\end{array}$ & Remarks \\
\hline \multicolumn{6}{|c|}{ October 7, 2020-Continued } \\
\hline B25 & $\begin{array}{l}\text { Big Lost River at Arco-Minidoka Road } \\
\text { crossing (W } 2400 \text { N) at Arco, ID }\end{array}$ & 0 & - & - & \\
\hline B26 & $\begin{array}{l}\text { Big Lost River at Highway } 20 \text { crossing, } \\
\text { at Arco, ID }\end{array}$ & $0.37 \pm 0.04$ & - & $(+) 0.37 \pm 0.04$ & G \\
\hline B27 & Big Lost River near Arco, ID ${ }^{1}$ & 0 & 一 & - & \\
\hline \multicolumn{4}{|c|}{ Overall net gain $(+)$ or loss $(-)$ throughout the lower reach: } & - & \\
\hline
\end{tabular}

${ }^{1}$ Real-time U.S. Geological Survey streamgage. Measurement uncertainty value equal to 0 indicates that a streamgage reading was used in place of a streamflow measurement.

In the upper reach, net streamflow losses were greater than uncertainty for each subreach between B01 and B03 but uncertainty exceeded the small losses and gains between B03 and B06 (fig. 5; table 6). Although overall measurement uncertainties were less during the March 2021 measurement event compared to previous measurement events, the small loss in the B03-B04 and gains in the B04-B05 and B05-B06 subreaches were less than the uncertainty for each of those measurements. Overall, streamflow in the upper reach had a net loss of $23.0 \pm 5.80 \mathrm{ft}^{3} / \mathrm{s}$ (fig. 5; table 6).

In the middle reach, each subreach had a streamflow loss greater than measurement uncertainties (fig. 5; table 6) and no streamflow was observed in the diversions and tributaries, which helped minimize propagated uncertainty associated with main-stem losses. Unlike the March and October 2019 measurement events but consistent with the October 2020 measurement event, measurements in the B09-B10 subreach showed a loss $\left(21.3 \pm 2.44 \mathrm{ft}^{3} / \mathrm{s}\right)$. The net overall streamflow loss in the middle reach was $67.9 \pm 5.89 \mathrm{ft}^{3} / \mathrm{s}$ (fig. 5; table 6).

In the lower reach, the East Side and West Side Ditches were not diverting streamflow and the remaining streamflow $\left(14.2 \pm 0.43 \mathrm{ft}^{3} / \mathrm{s}\right)$ downstream from the Moore Diversion was lost in the B11-B12 subreach (fig. 5; table 6). All subreaches downstream from B12 were dry (fig. 5; table 6) during the March 2021 measurement event. 


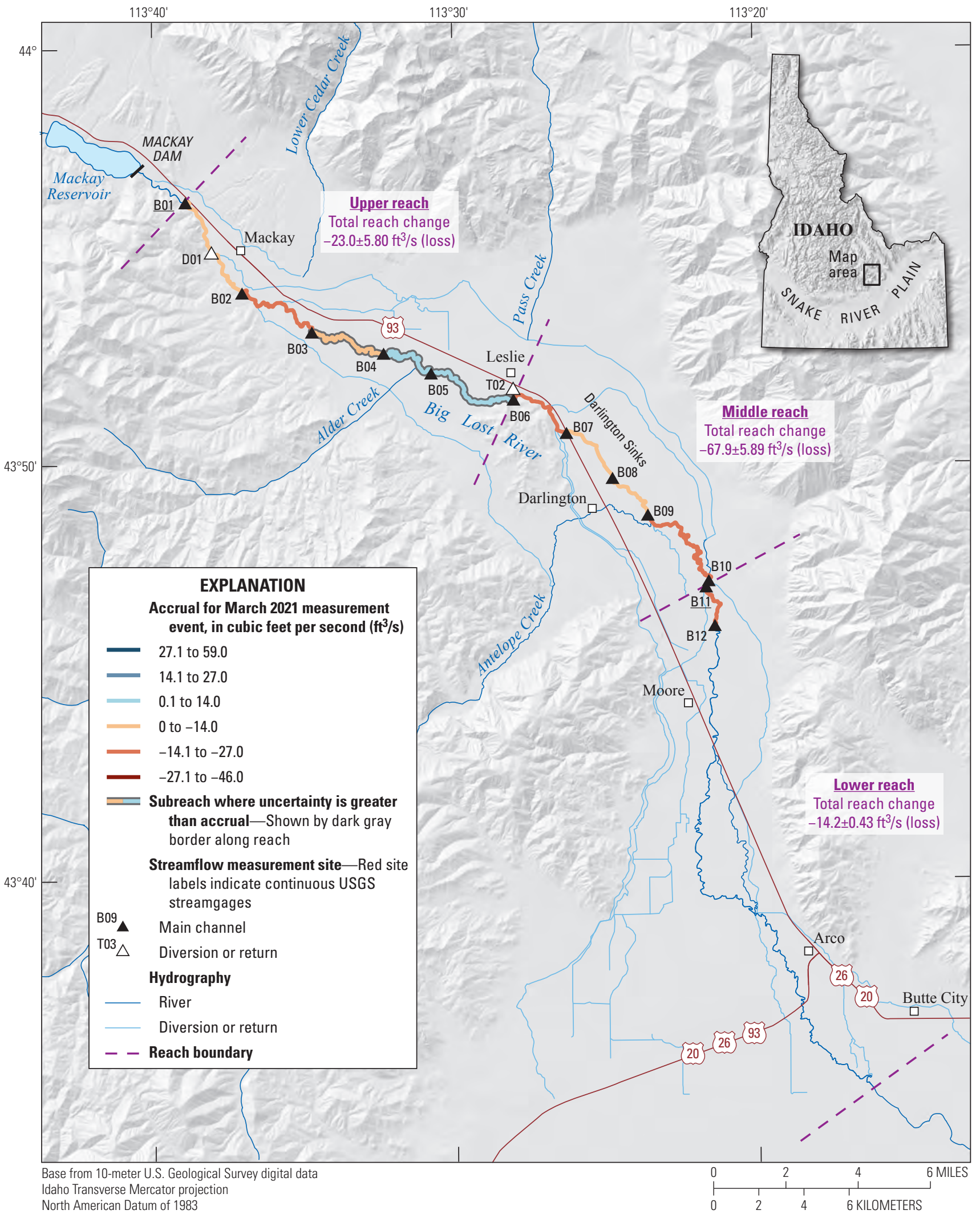

Figure 5. Gaining and losing reaches and subreaches on the Big Lost River, south-central Idaho, March 2021. USGS, U.S. Geological Survey; \pm , plus or minus. 
Table 6. Summary of streamflow, associated estimates of uncertainty, and streamflow gains and losses on measured reaches and subreaches in the Big Lost River Valley, south-central Idaho, March 30, 2021.

[Location of sites is shown in figure 1. See table 1 for site names according to river miles. Values at streamgages represent instantaneous measurement rather than daily mean streamflows. Site name: ID, Idaho; N, North; Rd, Road; W, West. Remarks: L, losing reach; U, uncertainty of measurements in subreach are greater than measured accrual; Abbreviations and symbols: No., number; $\mathrm{ft}^{3} / \mathrm{s}$, cubic feet per second; \pm , plus or minus; 一, no data]

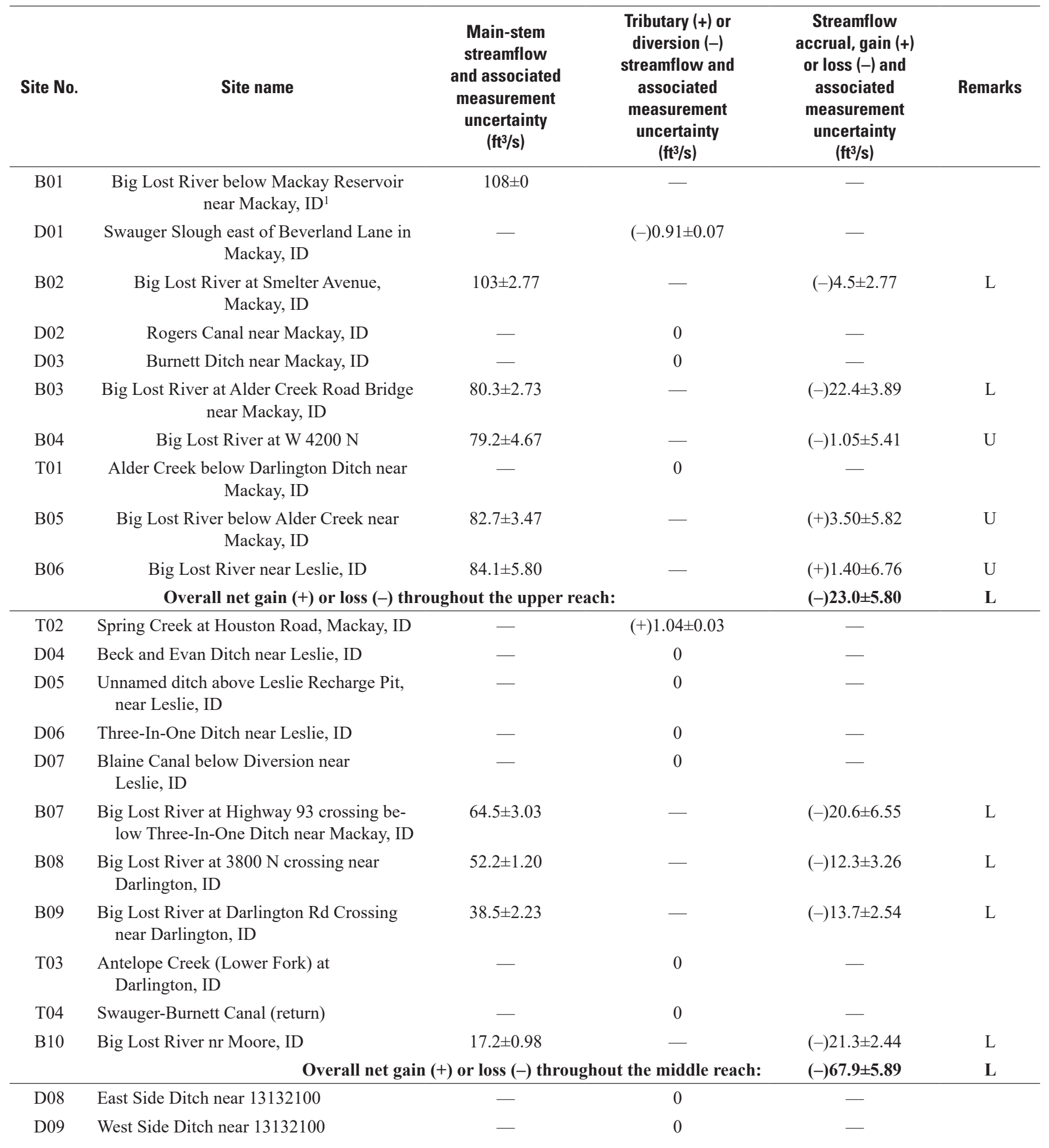


Table 6. Summary of streamflow, associated estimates of uncertainty, and streamflow gains and losses on measured reaches and subreaches in the Big Lost River Valley, south-central Idaho, March 30, 2021.—Continued

[Location of sites is shown in figure 1. See table 1 for site names according to river miles. Values at streamgages represent instantaneous measurement rather than daily mean streamflows. Site name: ID, Idaho; N, North; Rd, Road; W, West. Remarks: L, losing reach; U, uncertainty of measurements in subreach are greater than measured accrual; Abbreviations and symbols: No., number; $\mathrm{ft}^{3} / \mathrm{s}$, cubic feet per second; \pm , plus or minus; - , no data]

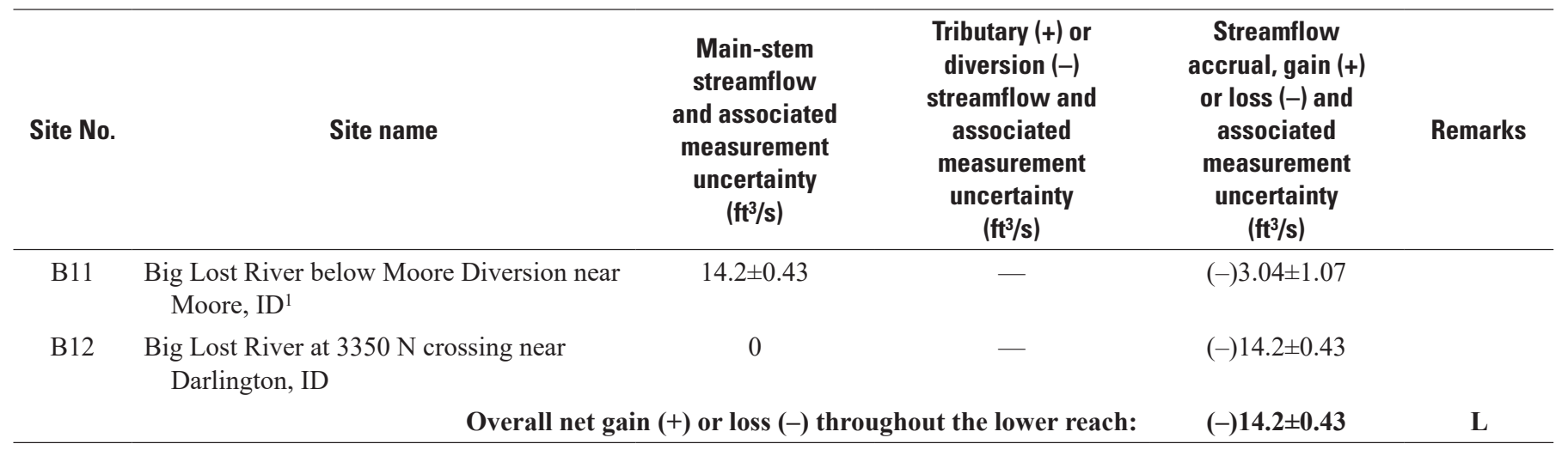

${ }^{1}$ Real-time U.S. Geological Survey streamgage. Measurement uncertainty value equal to 0 indicates that a streamgage reading was used in place of a streamflow measurement.

\section{Discussion}

Streamflow gains and losses in the upper, middle, and lower reaches varied between measurement events depending on surface-water supply, groundwater conditions, hydrogeologic factors, and water-management practices. In the upper reach, gaining and losing subreaches varied in magnitude and location between measurement events and years (fig. 6). The largest subreach gains and losses occurred during the two 2019 events, whereas smaller changes and greater relative uncertainties occurred during the October 2020 and March 2021 events. Total reach change was similar to the magnitude of the uncertainty (about $10 \mathrm{ft}^{3} / \mathrm{s}$ ) in the first three measurement events. Conversely, there was a net loss $\left(23.0 \pm 5.80 \mathrm{ft}^{3} / \mathrm{s}\right)$ during the last measurement event. In the middle reach, net losses consistently occurred through the Darlington Sinks during each measurement event, and the subreach upstream from Moore Diversion gained during the 2019 events and lost during the 2020 and 2021 measurement events. Overall, the middle reach showed large losses (about $40-85 \mathrm{ft}^{3} / \mathrm{s}$ ) in every event except October 2019, when the loss was small and the same magnitude as the uncertainty $\left(7.36 \pm 9.91 \mathrm{ft}^{3} / \mathrm{s}\right)$. In the lower reach, upstream water management exerted primary control on streamflow past the Moore Diversion, and only the 2019 events had streamflow below the diversion. Subreach gains and losses generally were small, with high uncertainty relative to changes in the upper reaches and large losses over the entire lower reach (about 40-50 ft $3 / \mathrm{s}$; fig. 6).

Annual precipitation during water years 2017-21 strongly influenced the overall quantity of water and surface-water supply in the basin and subsequently influenced surface-water/ groundwater interactions estimated in this study. Snow water equivalent is an important driver of total annual precipitation in the Big Lost River Basin and is used here in conjunction with total annual precipitation (Natural Resources Conservation Service, 2021b) because the latter was not available for water year 2021 during report preparation. The surface-water supply index combines streamflow forecasts (which are based on snow water equivalent) and reservoir carryover to predict surface-water availability for spring and summer use (Natural Resources Conservation Service, 2017, 2018, 2019, 2020, 2021a). Snow water equivalent on May 1 of water year 2019 was 108 percent of the median (fig. $7 A$ ), and the surface-water supply index was near normal ( 0.6 ; fig. 7C). Water year 2019 also followed a very high-water year (2017) and a close-to-average water year (2018, fig. 7A-7C). In contrast, the May 1 snow water equivalent for water years 2020 and 2021 was substantially lower than the median (48 and 36 percent, respectively; fig. $7 A$ ), and the surface-water supply index was below and much below normal, respectively $(-2.1$ and -3.8 , fig. $7 C)$. Snow water equivalent, total precipitation, and water supply, therefore, were near normal leading up to the March and October 2019 measurement events, and notably low preceding the October 2020 and March 2021 events (except for total precipitation, which was not available for 2021 during report preparation). The available water in the basin, in turn, directly affected the regulation of surface water during the measurement events. Greater quantities of nonirrigation streamflow were released from the reservoir preceding and during the 2019 events and streamflow was allowed past the Moore Diversion, whereas streamflows were highly managed during October 2020 and releases were minimal during March 2021. 


\section{A. March 2019}
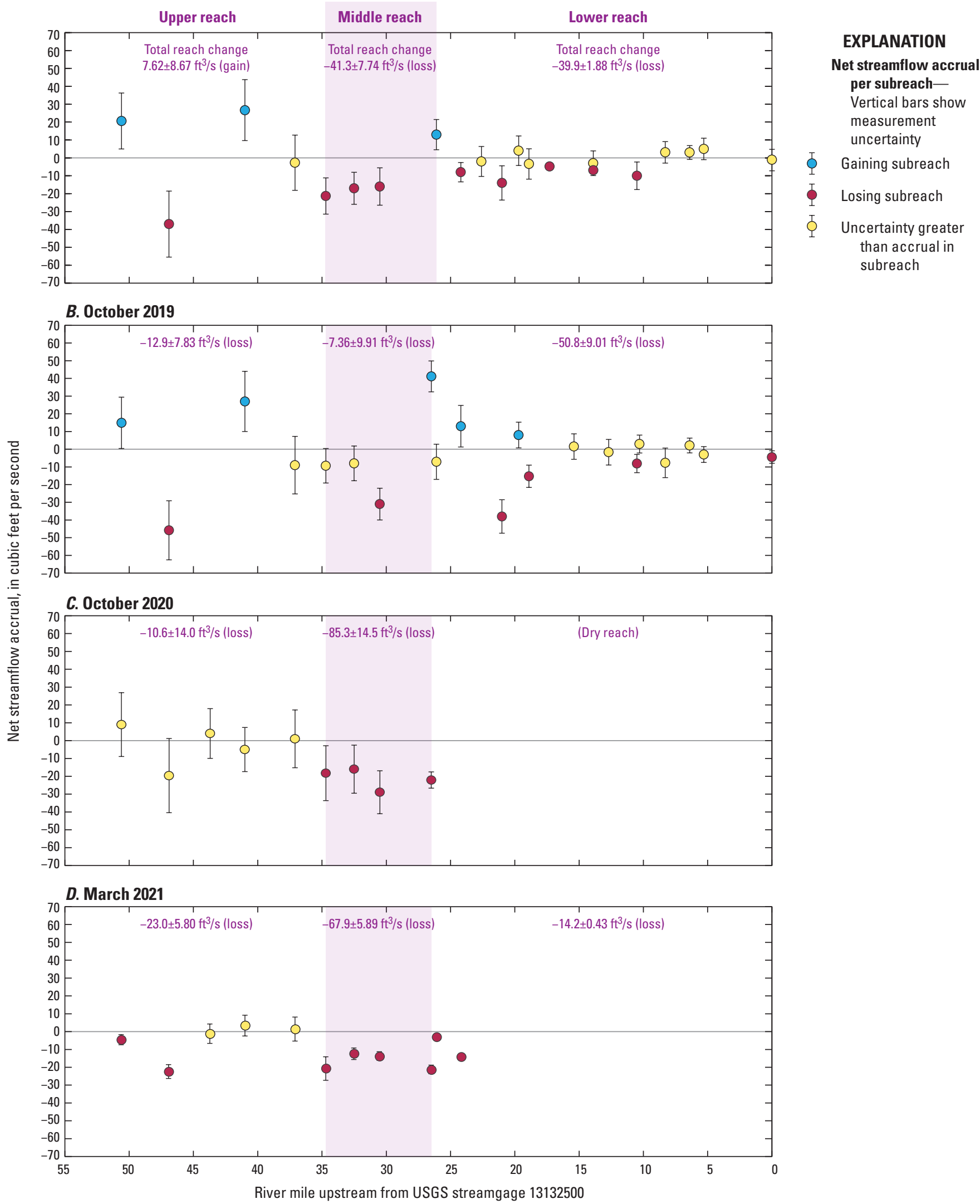

Figure 6. Comparison of measured streamflow gain and loss with measurement uncertainty in each subreach, Big Lost River Valley, south-central Idaho. Streamflow measurement locations are shown in figure 1. USGS, U.S. Geological Survey; $\mathrm{ft}^{3} / \mathrm{s}$, cubic feet per second; \pm , plus or minus. 

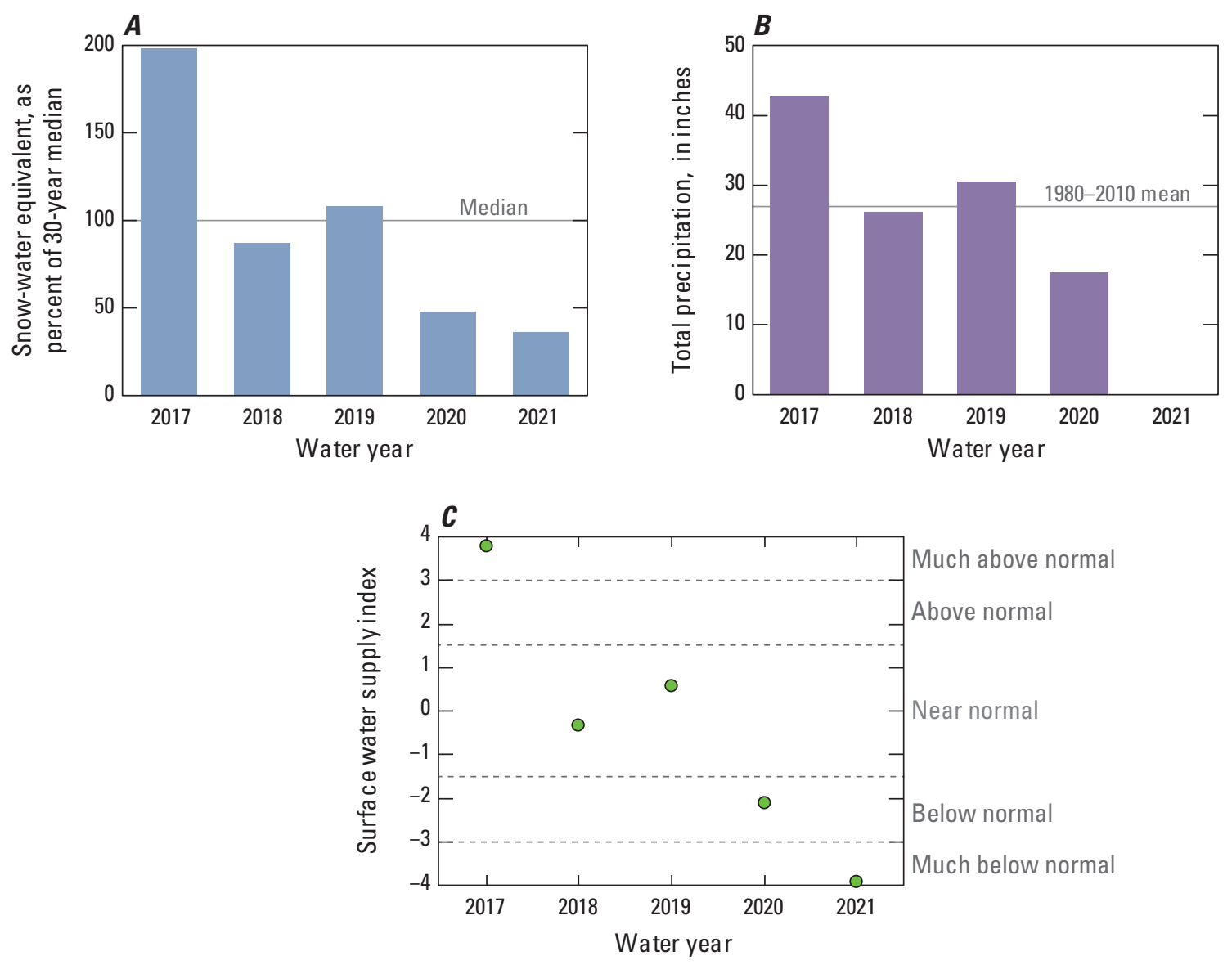

Figure 7. Snow water equivalent on May 1, 2017-21, compared to median for Snow Telemetry (SNOTEL) sites, for water years 2017-21 (A); total annual precipitation for water years 2017-20 (B); and surface-water supply index for water years 2017-21 $(C)$, in the Big Lost River Basin, south-central Idaho. Snow water equivalent and surface-water supply index analyses for the Big Lost River Basin from Natural Resources Conservation Service (2017, 2018, 2019, 2020, 2021a). Total annual precipitation data, averaged for five SNOTEL sites in the Big Lost River Basin (Bear Canyon, Hilts Creek, Lost-Wood Divide, Smiley Mountain, and Stickney Mill), from Natural Resources Conservation Service (2021b). Total annual precipitation data were not available for 2021 at the time of report preparation.

Patterns in streamflow gains and losses in the upper reach between Mackay and Leslie, therefore, likely were influenced by aquifer depth, width, lithology and surface-water supply. The alluvial fill aquifer near Mackay is relatively narrow and shallow, with groundwater close to the land surface (Zinsser, 2021). Historically, net gains and net losses have been observed in the upper reach depending on water supply (Stearns and others, 1938) and river stage (Crosthwaite and others, 1970). In this study, the upper reach between Mackay and Leslie had a net gain $(7.62 \pm 8.67 \mathrm{ft} / \mathrm{s}$; table 3$)$ and a net loss (12.9 $\pm 7.83 \mathrm{ft}^{3} / \mathrm{s}$; table 4) during the March 2019 and October 2019 measurement events, respectively. Measurement uncertainty was greater than subreach gains and losses during the October 2020 and March 2021 measurement events, both low water years (fig. 7). Although streamflow in the Big Lost River was highest during the October 2020 measurement event, measurement uncertainty also was high partly because of poor measurement cross sections that were improved during the March 2021 measurement event. The overall net change was similar to the uncertainty in October $2020(10.6 \pm 14.1$ $\mathrm{ft}^{3} / \mathrm{s}$; table 5) but showed a net loss in March 2021 (23.0 5.80 $\mathrm{ft}^{3} / \mathrm{s}$; table 6). Overall, subreach streamflow gains and losses were greater in high water years and lesser in lower water years, suggesting that surface-water/groundwater interactions in this reach increase during periods with more abundant water.

In the middle reach, net streamflow losses in the Darlington Sinks were estimated during each measurement event (fig. 6) and are consistent with previous investigations (Debler and others, 1931; Stearns and others, 1938; Crosthwaite and others, 1970; Rice and Boyd, 2008). Although limited in record length, the shallow wells at well cluster site IDWR-10, located between B06 and B07, indicate a strong, downward vertical gradient in groundwater potentiometric 
surface in this area (fig. 8). Thus, streamflow losses through the Darlington Sinks likely are driven by hydrogeologic conditions, including coarsening alluvial fill and valley (and hence, aquifer) widening, which lower the groundwater altitude relative to the land surface (Zinsser, 2021).

In the subreach upstream from the Moore Diversion (B09-B10), hydrogeologic controls and changes in groundwater potentiometric surface deriving from variable watersupply years affected patterns of streamflow gains and losses. Historical streamflow gains upstream from the Moore Diversion are influenced by valley (aquifer) constriction and groundwater recharge (Zinsser, 2021); the B09-B10 subreach was gaining during the March and October 2019 measurement events (average water year) but losing during the October 2020 and March 2021 measurement events

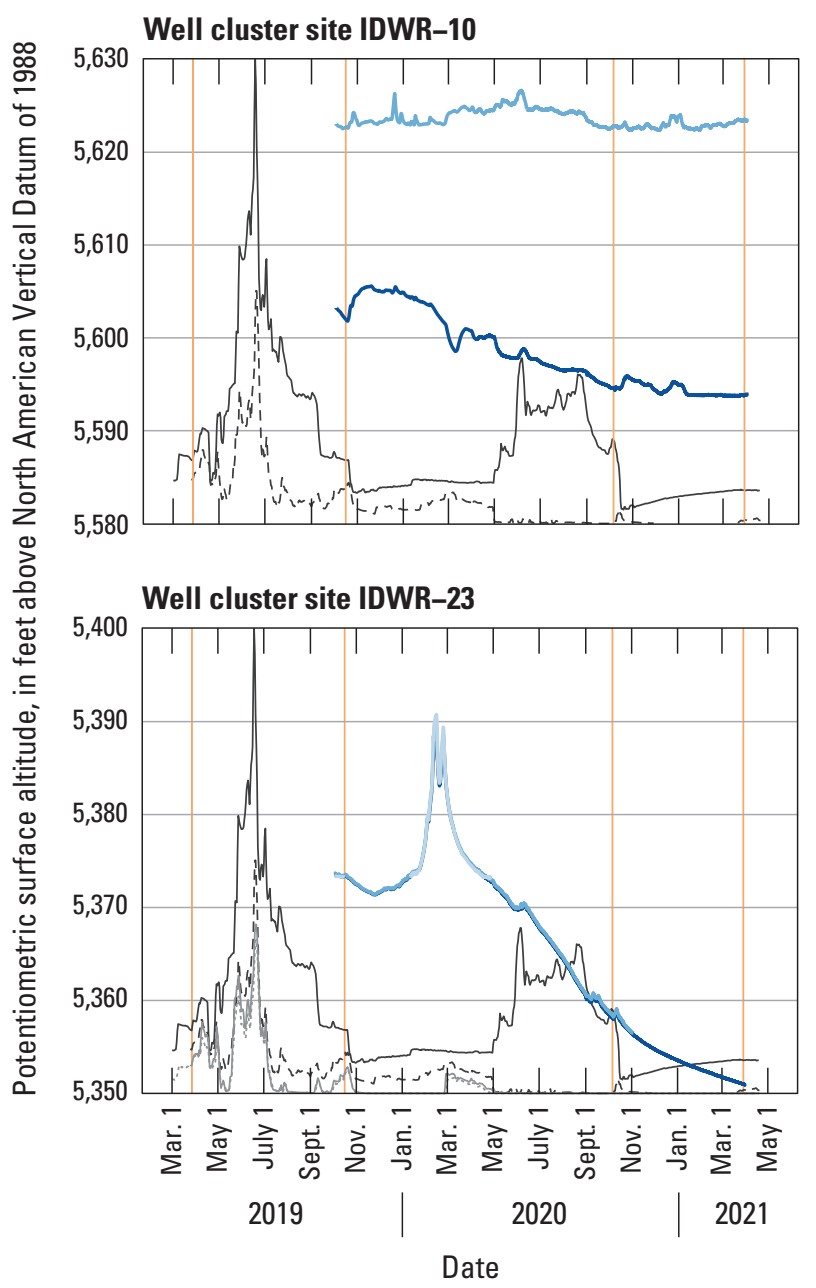

(below-average water years; fig. 6). Potentiometric surface maps show that regional groundwater potentiometric surface altitudes decreased between Leslie and Arco from March 2019 to March 2021 (fig. 9) and from October 2019 to October 2020 (fig. 10). Although the regional monitoring well network cannot fully resolve groundwater surfaces with respect to river altitude, the well cluster data provides insight into the groundwater gradient close to the river. Groundwater levels in shallow wells at the IDWR-14 well cluster site indicated a slight upward vertical gradient during the October 2019 sampling event, which corresponded with a $41.1 \pm 8.72 \mathrm{ft}^{3} / \mathrm{s}$ net gain in the adjacent Big Lost River subreach, and downward vertical gradients during the 2020 and 2021 events that showed net losses in the adjacent reach (figs. 6 and 8).

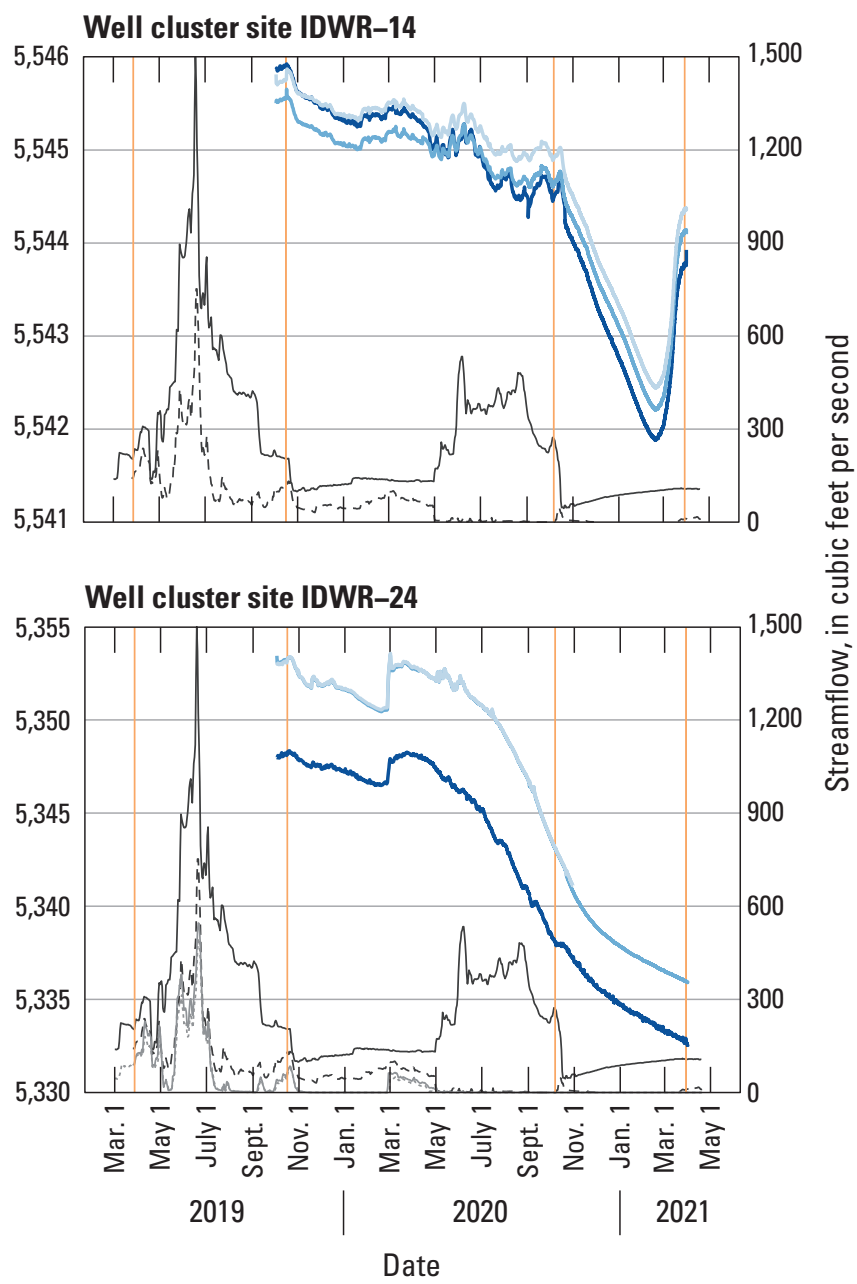

\section{EXPLANATION}

Well total depth
$-\quad 20 \mathrm{feet}$
$-\quad 40 \mathrm{feet}$
$-\quad 60 \mathrm{feet}$

Figure 8. Groundwater potentiometric surface altitudes in shallow wells at well cluster sites and Big Lost River streamflow at select streamgages in the Big Lost River Valley, south-central Idaho, 2019-21. Vertical axis scale varies by an order of magnitude between each graph. IDWR, Idaho Department of Water Resources. 


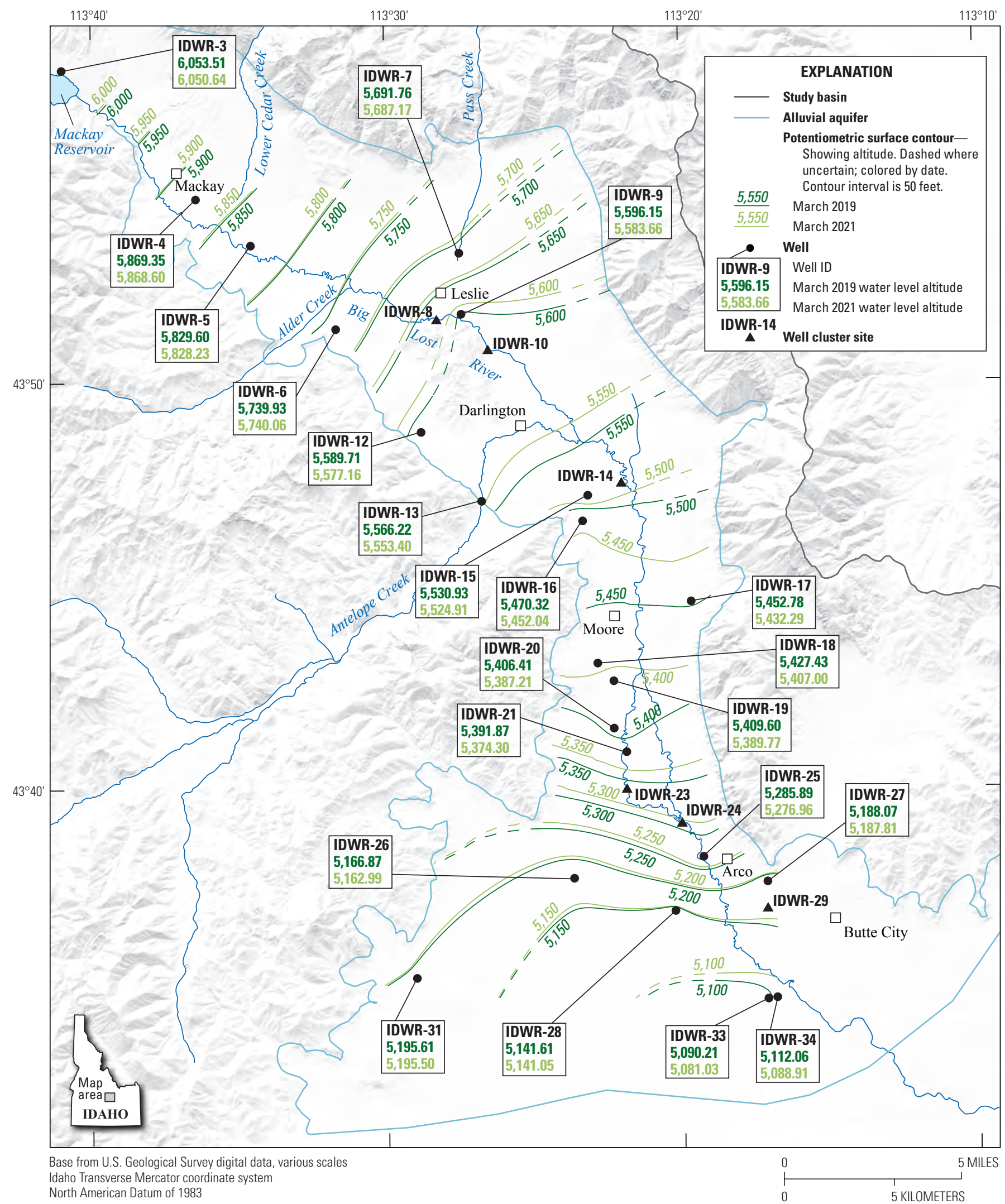

Figure 9. Groundwater potentiometric surface altitudes in Big Lost River Valley, south-central Idaho, March 2019 and March 2021. Well altitudes could not be uniformly referenced to a vertical datum. IDWR, Idaho Department of Water Resources. 


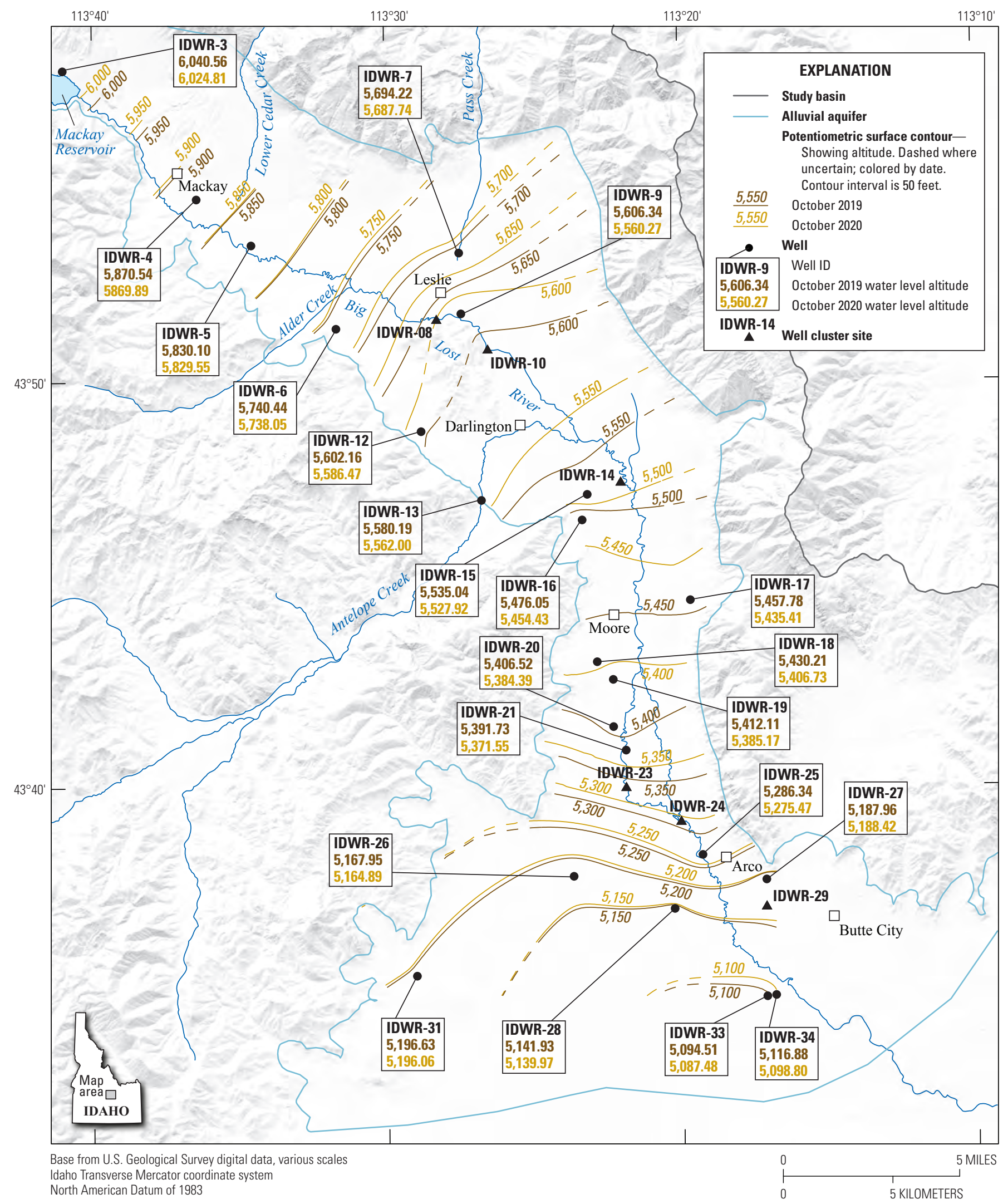

Figure 10. Groundwater potentiometric surface altitudes in Big Lost River Valley, south-central Idaho, October 2019 and October 2020. Well altitudes could not be uniformly referenced to a vertical datum. IDWR, Idaho Department of Water Resources. 
Thus, streamflow gains during the 2019 events occurred with elevated groundwater levels and were consistent with previous reports (Stearns and others, 1938; Crosthwaite and others, 1970). Decreased groundwater levels between the 2019 and 2020-2021 measurement events may have contributed to streamflow losses in subreach B09-B10 in the later events. Losses in this reach have not been noted previously, but most investigations focused on broader scale patterns (Stearns and others, 1938; Crosthwaite and others, 1970) and although Rice and Boyd (2008) made measurements at a similar scale, 2007 was a low water year following two high water years (Clark, 2022). Losses in this reach likely have occurred in other time periods but have not been measured or reported. Seasonal and interannual fluctuations in the groundwater potentiometric surface altitude between Leslie and Arco are influenced by annual precipitation; irrigation demand; and natural, managed and, incidental recharge (Clark, 2022; Zinsser, 2021). The results of this study further indicate that these fluctuations, in turn, affect patterns of streamflow gains and losses in the middle reach of the Big Lost River.

In the lower reach, surface-water management practices, in conjunction with overall water availability, strongly affect surface water, groundwater, and interactions therein. With abundant water supply during the 2019 events, streamflow was managed to allow water past the Moore Diversion in the Big Lost River channel. Gaining reaches upstream from Moore and near Arco during the 2019 events are consistent with previous reports (Stearns and others, 1938; Crosthwaite and others, 1970) and suggest that, under wetter conditions and with higher groundwater potentiometric surface altitudes (figs. 9-10), groundwater can still contribute streamflow to the Big Lost River below the Moore Diversion. Shallow wells in this part of the BLRV suggest no strong vertical gradient (well cluster sites IDWR-23 and IDWR-24) and show rapid water-level rise (well cluster site IDWR-24) in response to resumption of streamflows in the Big Lost River at streamgage 13132373 and substantial drawdown in water years 2020 and 2021 (fig. 8). Although unsurprising, this pattern shows the strong effect that water supply and surface-water management practices exert on streamflow and shallow groundwater in the lower reach.

\section{Summary}

The U.S. Geological Survey (USGS), in cooperation with the Idaho Department of Water Resources (IDWR), measured streamflow during four measurement events to improve the hydrologic understanding of interactions between the Big Lost River of south-central Idaho and the underlying alluvial aquifer. Crews consisting of USGS and IDWR personnel took 100 streamflow measurements at 46 main-stem, diversion, and tributary sites in the Big Lost River Valley during pre-irrigation and post-irrigation periods in March and October 2019, October 2020, and March 2021. Streamflow measurements throughout three reaches were incorporated in calculations to determine where the Big Lost River is gaining and losing streamflow.

Streamflow gains and losses in the Big Lost River were affected by basin water supply, hydrogeologic conditions, groundwater levels, and surface-water management. The 2019 events were preceded by three years with close-to- or abovemedian snowpack and close-to- or above-normal surface-water supply, whereas the 2020 and 2021 events occurred following 1 and 2 years, respectively, of low snowpack and belownormal surface-water supply. In the upper reach between Mackay and Leslie, overall streamflow gain or loss was similar to the magnitude of the uncertainty (about 10 cubic feet per second $\left[\mathrm{ft}^{3} / \mathrm{s}\right]$ ) for the first three events, and a net loss was estimated in the March 2021 event. Subreach gains and losses were greater during the wetter 2019 events and more subtle during the drier 2020 and 2021 events.

In the middle reach, large streamflow losses (42 percent or more of total streamflow) occurred in the Darlington Sinks during each event and are consistent with historical reports and hydrogeologic conditions, including coarsening alluvial fill, increased aquifer width, and increased depth to groundwater. The subreach upstream from the Moore Diversion showed streamflow gains during the 2019 events and streamflow losses during the 2020 and 2021 events, with synchronous declines in regional groundwater levels. Changes in regional groundwater potentiometric surface altitude (caused by changing water supply, water use, and recharge) therefore likely affect streamflow gains and losses in the middle reach.

In the lower reach, resumption of substantial streamflow past the Moore Diversion was associated with rapid recharge of shallow groundwater and large losses of surface water (about 40-50 ft $3 / \mathrm{s}$ ). However, small gains estimated in subreaches near Moore and Arco in 2019 suggest that groundwater can contribute to streamflows during wet periods. Thus, although seasonal variations existed between each measurement event, spatial patterns of gaining and losing subreaches were reasonably consistent throughout all four measurement events and generally agree with observations of gains and losses in previous studies.

This study provides an updated hydrologic understanding of interactions between the Big Lost River and the underlying aquifer. These results will contribute to water management in the basin, including improving water-budget calculations, water-right accounting, and representation of the Big Lost River Valley in the Enhanced Snake Plain Aquifer Model. 


\section{References Cited}

Bernal, R., 2016, Petition to designate a critical groundwater area in the Big Lost River Basin: Submission to the Idaho Department of Water Resources, docket \#P-CGWA-2016-001, 17 p., https://idwr.idaho.gov/wpcontent/uploads/sites/2/legal/P-CGWA-2016-001/P-CGWA2016-001-20160919-Petition-to-designate-the-Big-LostRiver-Basin-as-a-CGWA.pdf.

Bernal, R., and Broadie, M., 2017, Notice of withdrawal of petitions: Submission to the Idaho Department of Water Resources, docket \#P-CGWA-2016-001, 3 p., https://idwr. idaho.gov/wp-content/uploads/sites/2/legal/P-CGWA-2016001/P-CGWA-2016-001-20170620-Notice-of-Withdrawalof-Petitions.pdf.

Broadie, M., 2017a, Designation of Big Lost River Basin as a ground water management area (GWMA): Submission to the Idaho Department of Water Resources, docket \#P-CGWA-2016-001, 2 p., https://idwr.idaho.gov/wpcontent/uploads/sites/2/legal/P-CGWA-2016-001/P-CGWA2016-001-20170109-Broadie-Letter-re-designation-of-BigLost-River-Basin-GWMA.pdf.

Broadie, M., 2017b, Response to petition to create a critical ground water area in the Big Lost River Basin: Submission to the Idaho Department of Water Resources, docket \#P-CGWA-2016-001, 2 p. , https://idwr.idaho.gov/wpcontent/uploads/sites/2/legal/P-CGWA-2016-001/P-CGWA2016-001-20170123-Response-to-Petition-to-Create-aCGWA-in-the-Big-Lost-River-Basin.pdf.

Clark, A., 2022, Groundwater budgets for the Big Lost River Basin, south-central Idaho, 2000-19, chap. C of Zinsser, L.M., ed., Characterization of water resources in the Big Lost River Basin, south-central Idaho: U.S. Geological Survey Scientific Investigations Report 2021-5078-C, 111 p., https://doi.org/10.3133/sir20215078C.

Cohn, T., Kiang, J., and Mason, R., Jr., 2013, Estimating discharge measurement uncertainty using the interpolated variance estimator: Journal of Hydraulic Engineering, v. 139, no. 5, p. 502-510, https://doi.org/10.1061/(ASCE)HY.19437900.0000695 .

Crosthwaite, E.G., Thomas, C.A., and Dyer, K.L., 1970, Water resources in the Big Lost River Basin, south-central Idaho: U.S. Geological Survey Open-File Report 70-93, 109 p. [Also available at https://doi.org/10.3133/ofr7093.]

Debler, E.B., Carter, G.N., Crandall, L., Thompson, R.W., Lippincott, J.B., Volk, K.Q., and Livingston, D.C., 1931, Report of Board of Engineers on Big Lost River Idaho: Boise, Idaho State Board of Engineers, 12 p.
Idaho Department of Water Resources, 2013, Enhanced Snake Plain Aquifer Model Version 2.1-Final report: Idaho Department of Water Resources, 91 p., accessed April 6, 2021, at https://research.idwr.idaho.gov/files/projects/ espam/browse/ESPAM_2_Final_Report/ESPAM21FinalReport.pdf.

Idaho Department of Water Resources, 2021, Groundwater level data: Idaho Department of Water Resources Map and GIS data hub, accessed September 10, 2021, at https://dataidwr.opendata.arcgis.com/ and https://idwr.idaho.gov/waterdata/groundwater-levels/.

Livingston, D.C., 1931, Geological report on Big Lost River Valley: Boise, Idaho Bureau of Mines and Geology, 8 p.

Mueller, D.S., 2016, QRev-Software for computation and quality assurance of acoustic doppler current profiler moving-boat streamflow measurements - User's manual for version 2.8: U.S. Geological Survey Open-File Report 2016-1068, 87 p. [Also available at https://doi.org/10.3133/ ofr20161052.]

Mueller, D.S., Wagner, C.R., Rehmel, M.S., Oberg, K.A., and Rainville, F., 2009, Measuring discharge with acoustic Doppler current profilers from a moving boat: U.S. Geological Survey Techniques and Methods, book 3, chap. A22. [Also available at https://doi.org/10.3133/tm3A22.]

Natural Resources Conservation Service, 2017, Idaho water supply outlook report, May 1, 2017: Natural Resources Conservation Service, 32 p., https://www.nrcs.usda.gov/ wps/portal/nrcs/detailfull/id/snow/waterproducts/?cid=stelp rdb1241057.

Natural Resources Conservation Service, 2018, Idaho water supply outlook report, May 1, 2018: Natural Resources Conservation Service, 31 p., https://www.nrcs.usda.gov/ $\mathrm{wps} / \mathrm{portal} / \mathrm{nrcs} /$ detailfull/id/snow/waterproducts/?cid=stelp rdb1241057.

Natural Resources Conservation Service, 2019, Idaho water supply outlook report, May 1, 2019: Natural Resources Conservation Service, 29 p., https://www.nrcs.usda.gov/ wps/portal/nrcs/detailfull/id/snow/waterproducts/?cid=stelp rdb1241057.

Natural Resources Conservation Service, 2020, Idaho water supply outlook report, May 1, 2020: Natural Resources Conservation Service, 27 p., https://www.nrcs.usda.gov/ wps/portal/nrcs/detailfull/id/snow/waterproducts/?cid=stelp rdb1241057.

Natural Resources Conservation Service, 2021a, Idaho water supply outlook report, May 1, 2021: Natural Resources Conservation Service, 31 p., https://www.nrcs.usda.gov/ $\mathrm{wps} / \mathrm{portal} / \mathrm{nrcs} /$ detailfull/id/snow/waterproducts/?cid=stelp rdb1241057. 
Natural Resources Conservation Service, 2021b, Report generator 2.0: Natural Resources Conservation Service web page, accessed May 3, 2021, at https://wcc.sc.egov.usda.gov/ reportGenerator/.

Oberg, K., and Mueller, D.S., 2007, Validation of streamflow measurements made with acoustic doppler current profilers: Journal of Hydraulic Engineering, v. 133, no. 12, p. 1421-1432. [Also available at https://doi.org/10.1061/ (ASCE)0733-9429(2007)133:12(1421).]

Rantz, S.E., 1982, Measurement and computation of streamflow: U.S. Geological Survey Water Supply Paper 2175, v. 1-2, 611 p. [Also available at https://doi.org/10.3133/ wsp2175.]

Rice, J.B.J., and Boyd, K., 2008, Big Lost River Darlington Sinks geomorphology, loss rates and conceptual alternatives development: Prepared for Trout Unlimited, Big Lost River Irrigation District, and Water District \#34, 88 p.

Riggs, H.C., 1972, Low-flow investigations U.S. Geological Survey Techniques and Methods, book 4, chap. B1. [Also available at https://doi.org/10.3133/twri04B1.]

Simonds, F.W., and Sinclair, K.A., 2002, Surface water-ground water interactions along the lower Dungeness River and vertical hydraulic conductivity of streambed sediments, Clallam County, Washington, September 1999-July 2001: U.S. Geological Survey Water-Resources Investigations Report 2002-4161.[Also available at https://doi.org/ 10.3133/wri024161.]

Stearns, H.T., Crandall, L., and Steward, W.G., 1938, Geology and ground-water resources of the Snake River Plain in southeastern Idaho: U.S. Geological Survey Water Supply Paper 774, 268 p. plus 31 pl. p. [Also available at https://doi.org/10.3133/wsp774.]
Sukow, J., 2017, Groundwater in the Big Lost River valley: Boise, Idaho Department of Water Resources Memo, 37 p., https://idwr.idaho.gov/wp-content/uploads/sites/2/legal/PCGWA-2016-001/P-CGWA-2016-001-20170206-IDWRStaff-Memo-Re-BLRV-by-Jennifer-Sukow.pdf.

Turnipseed, D.P., and Sauer, V.B., 2010, Discharge measurements at gaging stations: U.S. Geological Survey Techniques and Methods, book 3, chap. A8, 87 p. [Also available at https://doi.org/10.3133/tm3A8.]

U.S. Geological Survey, 2021a, StreamStats: U.S. Geological Survey web-based application, accessed February 2021, at http://streamstats.usgs.gov/ss/.

U.S. Geological Survey, 2021b, USGS surface-water data for the Nation, in USGS water data for the Nation: U.S. Geological Survey National Water Information System database, accessed February 2021, at https://doi.org/10.5066/ F7P55KJN. [Surface-water data are directly accessible at https://waterdata.usgs.gov/nwis/sw.]

Wheeler, J.D., and Eddy-Miller, C.A., 2005, Seepage investigation on selected reaches of Fish Creek: Teton County, Wyoming, 2004: U.S. Geological Survey Scientific Investigations Report 2005-5133. [Also available at https://doi.org/10.3133/sir20055133.]

Zinsser, L.M., 2021, Hydrogeologic framework for the Big Lost River Basin, south-central Idaho, chap. A of Zinsser, L.M., ed., Characterization of water resources in the Big Lost River Basin, south-central Idaho: U.S. Geological Survey Scientific Investigations Report 2021-5078-A, 42 p., https://doi.org/10.3133/sir20215078A. 

Publishing support provided by the U.S. Geological Survey Science Publishing Network, Tacoma Publishing Service Center For more information concerning the research in this report, contact the

Director, Idaho Water Science Center

U.S. Geological Survey

230 Collins Road

Boise, Idaho 83702-4520

https://www.usgs.gov/centers/id-water 


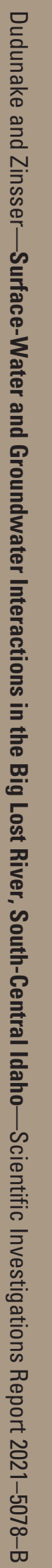

